16)

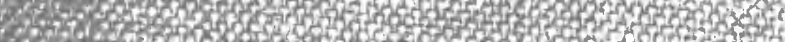

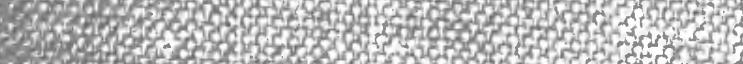

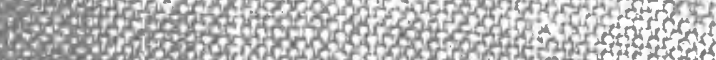

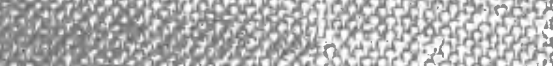

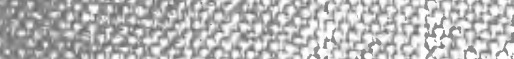

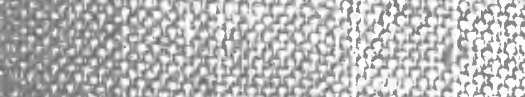

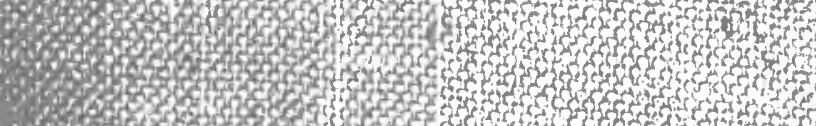

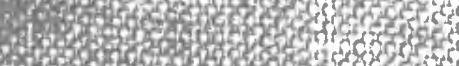

3.7030

\%

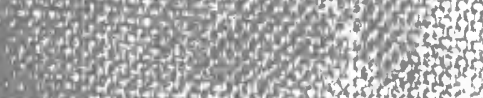

0.6.

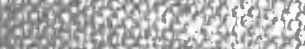

3.83)

3. 30 of

*3. 050

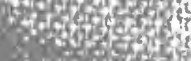

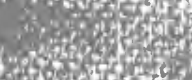

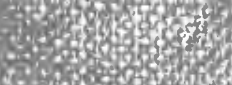

H. 30

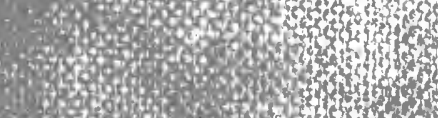

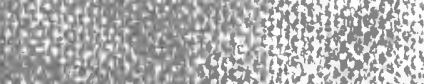

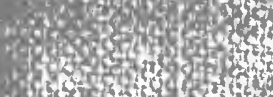

30 cos

7.

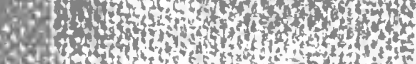

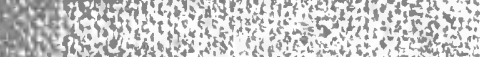

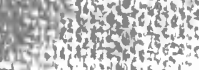

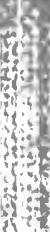

8

es

it

4 (n)

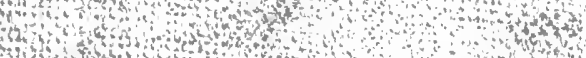

(3)

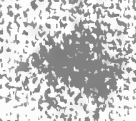

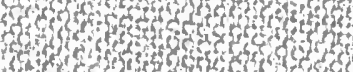

की

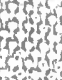

Af 3 s

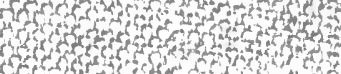

fot 5 se

of

(1)

3

(t)

\title{
int
}

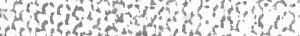

cistis

tivis

sicts

(3)

to es

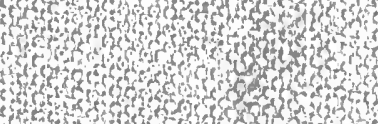

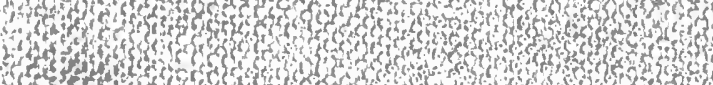
ctototits 


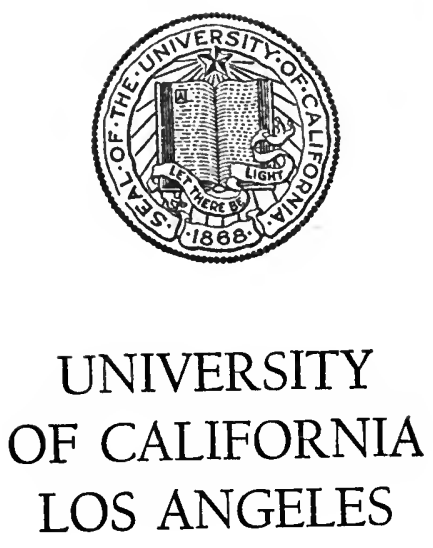

SCHOOL OF LAW

LIBRARY 
H a Rowian 
Digitized by the Internet Archive in 2007 with funding from Microsoft Corporation 




\title{
THE
}

\section{LAW RELATING TO}

\section{CONFLICTING USES OF ELECTRICITY}

\author{
AND \\ ELECTROLYSIS
}

\author{
BY \\ GEORGE F. DEISER
}

OF THE PHILADELPHIA BAR

PHILADELPHIA

T. \& J. W. JOHNSON CO. 


\section{$T$ \\ D $3683 e$ \\ 1911}

\section{Copyright, 1911}

BY

T. \& J. W. JOHNSON CO.

$$
\begin{gathered}
32.4181 \\
12.3 .59 \\
544
\end{gathered}
$$




\section{PREFACE}

The purpose of this volume is to treat exhaustively a very limited and very recent development of the law. The decisions upon the subject are not numerous, and the author has tried to include all that have appeared to the present date. This is the first attempt, to the author's knowledge, to collect the cases upon Electrolysis, and as they will doubtless have a far-reaching influence, they have been discussed very fully. The author desires to express his appreciation of the kindly services rendered by John W. Wright, E. E., of the Bell Telephone Company of Pennsylvania, for many useful suggestions and through discussion with whom the writer first became interested in the subject.

The facts of some of the cases have been stated at times in great detail as the lawyer who conducts litigation of this kind is interested to know how far affirmative proof must go to justify the court in interfering. It is for that reason, that in one instance, the plaintiff's bill of complaint has been given in full. The writer will appreciate information of any omissions that may come to the knowledge of those who read this little work. He has striven to make it complete and useful; apparently the dominant tests of the value of modern effort.

\section{George F. Deiser.}

Philadelphia, September I, I9II. 



\section{CONTENTS}

\section{PART I.}

THE LAW RELATING TO THE USE OF ELECTRICITY

\section{CHAPTER I.}

LEGAL POSITION OF ELECTRICAL COMPANIES.

1. Franchise holders distinguished from eitizens.

2. Conflicts in the exercise of franchises.

3. Scope of this inquiry.

4. Conflicting uses of Electricity.

5. Nature of franchises.

6. Fundamental principles.

6a. Telephone companies and telegraph companies, a burden upon the highway.

7. Telephone company is a telegraph company.

8. They must not interfere with public travel.

9. The English doctrine.

10. Street railways have no exclusive right to the highway.

11. The railway a dominant franchise.

\section{CHAPTER II.}

CONFLICTS IN THE USE OF ELECTRICITY PRODUCED BY STREET RAILWAYS.

12. The operating and construction of a railway cannot be enjoined if lawful.

13. Summary of principles.

14. The kind of relief open to a telephone company.

15. The telephone apparatus must be efficient.

\section{CHAPTER III.}

AGAINST WHAT, RELIEF MAY BE GRANTED.

16. A railway company not protected in aggression.

17. Acts constituting a nuisance may be restrained. 
18. Principles established in the case of Hudson, etc., v. Watervliet Turnpike Company.

19. The principles sound in view of the relinf sought.

20. Franchise holders may not encroach upon private property.

21. They must use the most efficient means at their command.

22. What are efficient means?

23. No exclusive right to use the earth as \& return circuit.

24. Interference with submarine cables.

25. Defective construction of a railway must be remedied.

\section{CHAPTER IV. \\ INJUNCTIONS AND OTHER REMEDIES.}

26. Invasion by a new franchise holder enjoinable.

27. Direct interference by a railway may be restrained.

28. Railway may be compelled to crect guards.

29. Injury due to lawful operation distinct from aggression.

30. Accommodation of conflicting franchises.

31. First franchise on given territory not exclusive.

32. Ordinances requiring guard wires.

33. Principle of dominant use of highway. Application.

\section{CHAPTER V.}

\section{ENGLISH AND CANADIAN DOCTRINES.}

34. The English point of view.

35. Effect of English doctrine. Application to submarine cable.

36. Doctrine of statutory immunity.

37. Canadian authorities.

38. Private persons cannot restrain exercise of electric franchises.

\section{CHAPTER VI.}

PRIORITY OF FRANCHISE AS CONFERRING VESTED RIGHTS.

39. First franchise holder must not be disturbed.

40. Priority in a given territory gives vested rights.

41. Exclusive franchises against public policy.

42. Invading companies may be restrained.

43. But private uses must give way to public ones. 


\section{CHAPTER VII.}

PRINCIPLES BEARING ON CONFLICTING USES OF ELECTRICITY.

44. Consequences of doctrine that railway is a dominant use of the highway.

45. Facts for the jury.

46. Statutory authority answers elaim that franchise is a nuisance.

47. Does the electric light facilitate travel?

48. The doctrine of Rylands v. Fletcher.

49. Contrast of English and American principles.

\section{CHAPTER VIII.}

ADJUSTMENT ON EQUITABLE PRINCIPLES. SUMMARY.

50. The equitable treatment of conflicting uses.

51. Relief where a railway unnecessarily interferes.

52. What kind of relief may be sought.

53. The street railway is a burden on country highways.

54. The discharge of electricity into the earth as a nuisance.

55. Summary of principles.

\section{PART II.}

\section{THE LAW RELATING TO ELECTROLYSIS}

\section{CHAPTER IX.}

\section{ELECTROLYSIS.}

56. Electrolysis-The problem. Definitions. The Peoria Case.

57. Statement of facts.

58. Determination of existence of electrolysis. Tracing the cause.

59. Notice to defendants.

60. Rapidity of electrolytic action. 
61. Elimination of possible explanations.

62. Differences in potential.

63. Suggested remedies.

64. Railways negative return system.

65. Summary of facts.

66. Conclusions of law.

67. Electrolysis a permanent and continuing injury.

68. License to operate a railway does not justify injury to others.

69. The injury results from defendant's acts.

70. The injury is actionable.

71. The remedy.

72. Investigation of possible remedies.

73. Metal consumed by electrolysis.

74. Bonding as a remedy.

75. Difference of potential necessary to produce electrolysis

76. Definition of electrical terms.

77. Electrolysis defined.

78. Court cannot specify kind of remedy.

79. Injunction to restrain injury by electrolysis.

80. Principles of general application.

81. Electricity a dangerous agent.

82. English cases of electrolysis.

83. Public and private duties of public service corporations.

84. Municipality may restrain electrolysis.

85. Faulty construction must be remedied.

86. Principles established.

87. Summary of the law relating to electrolysis. 


\section{TABLE OF CASES.}

A.

PAGE

Agincourt Steamship Co. v. Eastern Extension Co., 76 L. J.

(K. B.) 884 ,

American Telephone \& Telegraph Co. v. Morgan County

Telephone Co., 138 Ala. 597; 36 So. 178,

Angell \& Durfee on Highways, 3rd Ed., Sec. 2,

Atchison, T. \& S. F. Co. v. The Denver \& N. O. R. C., 110

U. S. 667 ,

Attorney-General v. Edison Telephone Co., of London, L.

R. 6 Q. B. D. 244,

B.

Bell Telephone Co. v. Belleville Elec. Light Co., 12 Ontario, 571 ,

Bell Telephone Co. v. Montreal Street Railway Co., 6 Q.

B. 223, (Rapports Judiciares de Quebec),

Birmingham Traction Co. v. Southern Bell Telephone Co., 119 Ala. 144; 24 So. 731,

Blanchard v. Western Union Telegraph Co., 60 N. Y. 510 ;

1 Am. Elec. Cas. 176,

Block v. Milwaukee St. Railway Co., 89 Wis. 371; 27 L.

R. A. 365; 61 N. W. 1101,

Board of Trade Telegraph Co. v. Barnett, 107 Ill. 507; 1

Am. Elec. Cas. 565,

Briggs v. Lewiston \& Auburn Horse R. R. Co., 79 Me. 363;

10 Atl. Rep. 47,

C.

Central Pennsylvania Telephone \& Supply Co. v. Wilkes-

Barre \& Westside Railway Co., 11 Pa. C. C. 417; 4 Am.

Elec. Cas. 260,

Central Union Telephone Co. v. Sprague Elec. Ry., etc. Co.

and the Akron St. R. R. Co., 2 Am. Elec. Cas. 307,

Chepstow Elec. Lt. \& Power Co. v. Chepstow Gas \& Coke

Consumers Co., L. R. (1905) 1 K. B. 198,

Chesapeake \& Potomac Telephone Co., The, v. Baltimore \&

Ohio Telegraph Co., 66 Md. 399; 7 Ala. Rep. 809,

Chicago v. Baer, 41 Ills. 306, 
Chicago Telephone Co. v. Northwestern Telephone Co., 199

Ills. $324 ; 64$ N. E. 329 , affirming 100 Ills. App. 57, 57, 58 Clara Killam, The, 39 L. J. 50,

Cogswell v. The New York, New Haven \& Hartford Railway

Co., 103 N. Y. $10 ; 8$ N. E. 537, 28, 87

Commonwealth v. West Chester, 9 Pa. C. C. 542 , 53

Consolidated Elec. Light Co. v. People's Elec. Light \& Gas

Co., 49 Ala. 372 ; 10 So. 440 ,

Cumberland Telegraph \& Telephone Co. v. The United Elec.

Ry. Co. 93 Tenn. 492; 29 S. W. 104; 27 L. R. A. 236, 76

Cumberland Telephone \& Telegraph Co. v. The United Elec.

Ry. Co., 42 Fed. Rep. 273; 12 L. R. A. 544; 3 Am.

Elec. Cas. 408,

$60,44,43$

D.

Davis v. Mayor, 14 N. Y. 506 ,

Davis v. Smith, 130 Mass. 113,

Dayton v. Railway Co., 26 Ohio C. C. R. 736,

E.

Eastern \& South African Telegraph Co. v. Cape Town

Tramways Co., L. R. App. Cas. 381, 119, 36, 32

Easton v. New York \& Long Branch Railway Co., 24 N. J.

Equity 49 ,

Easton F. Railroad Co., 24 N. J. Equity 58,

East Tennessee Telephone Co. v. Knoxville Street Railway

Co., 3 Am. Elec. Cas. 400,

East Tennessee Telephone Co. v. The Chattanooga Elec.

Street Railway Co., $2 \mathrm{Am}$. Elec. Cas. 323,

Edison Electric Light \& Power Co. v. Merehants' \& Manu-

facturers' Elec. Light, Heat \& Power Co., $200 \mathrm{~Pa}$. $209 ; 49$ A. 766 ,

9

87

3

6

6


Hobart v. Milwaukee, et., 27 Wis. 194,

Hudson v. Jersey City, 49 N. J. L. 303,

Hudson River Telephone Co. v. Watervliet Turnpike \& Railway Co., 135 N. Y. 393; 32 N. E. 148; 17 L. R. A. 674; 4 Am. Elec. Cas. 275,

Hussner v. Brooklyn City R. R., 114 N. Y. 437; 21 N. E. 1002 ,

I.

Illinois Central Railroad Co. v. City of Chicago, 141 Ills. 586 ; 30 N. E. 1036 ,

J.

Julia Bldg. Assn. v. Bell Telephone Co., 13 Mo. App. 477,

L.

Lahr v. Met. E. R. R. Co., 104 N. Y. 268, 10 N. E. 528

Lake shore \& M. S. Railroad Co. v. Chicago L. S. \& S. S.

Railway Co., 92 N. E. 989,

Lake St. Elec. Railway Co. v. Chicago, 183 Ills. $75 ; 55 \mathrm{~N}$. E. 721,

Lockhart v. Craig St. Railway Co., 135 Pa. 419; 21 Atl. Rep. 26,

Louisville Home Telephone Co. . Cumberland Telephone \& Telegraph Co., 111 Fed. Rep. 663, reversing 110 Fed. Rep. 593,

M.

Marsh v. Lake Shore Elec. Railway Co., 5 Ohio C. C. R. (N. S.) 405 ,

Midwood \& Co., Ltd. v. Manchester Corporation, L. R. (1905) 2 K. B. 597,

Monongahela L. \& R. Co. v. Rose Hill Elec. Lt. Co., 30 P. L. J. (Pa.) 301; 9 Am. Elec. Cas. 838,

Montgomery Lt. \& W. P. Co. v. Citizens' L. H. \& P. Co., 147 Ala. 359; 40 So. 981; 9 Am. Elec. Cas. 776,

Morris \& Essex Railway Co. v. Newark Passenger Railway Co., 51 N. J. Equity 379; 29 Atlantic 184,

Mt. Adams \& Eden Park Incline, etc., Co. v. Howard Winslow, 3 Ohio C. C. R. 425; 2 Am. Elec. Cas. 262, 27, 6

N.

National Telephone Co. v. Baker, L. R. (1893) $2 \mathrm{Ch}$. 186 , $49,118,125$ 
Nebraska Telephone Co. v. York Gas \& Elec. Co., 27 Neb. 284; 43 N. W: 126; 3 Am. Elec. Cas. 364,

New York Cable Co. v. Meyer, etc., 104 N. Y. $1 ; 10$ N. E. 332 ,

Northwestern Telephone Co. v. Twin City Telephone Co., 89

Minn. 495; 95 N. W. 460,

P.

Panton v. Holland, 17 Johns (N. Y.) 99,

Paris Elec. Light \& Railway Co. v. Southwestern Telegraph \& Telephone Co., 5 Am. Elec. Cas. 262,

Pelton v. East Cleveland Railroad Co., 3 Am. Elec. Cas. 215, 53

Pennsylvania Co. v. City of Chicago, 181 Ills. 289; 54 N. E. 825 ,

Pennsylvania R. R. Co. v. Montgomery County Passenger Railway Company, $167 \mathrm{~Pa}$. 62; 31 Atlantic Rep. 468,

Pennsylvania Telephone Co. v. Hoover, 24 Pa. Super. Ct. 96,

People v. Kerr, 27 N. Y. 188,

People, etc. v. O'Brien, 111 N. Y. 1; 18 N. E. 692,

People ex rel. N. Y. E. L. Co. v. Squire, 107 N. Y. 593; 14 N. E. 500 ,

Peoria Waterworks v. Peoria Railway Co., 181 Fed. Rep. 990 ,

R.

Radeliff v. Mayor, 4 N. Y. 195, 198,

Railway Co. v. Chicago, 183 Ills. $75 ; 55$ N. E. 721 ,

Railway Co. v. Heisel, 38 Mich. 62,

Railway Co. v. Telegraph Association, 48 Ohio 390; $27 \mathrm{~N}$.

E. 890 ; 12 L. R. A. 534 ,

Rhodes v. Dunbar, $57 \mathrm{~Pa} .274$,

Rich v. Chicago, 152 Ills. 18; 38 N. E. 255,

Richmond v. Southern Bell Telephone Co., 174 U. S. 761, 70, 8 Rule in Rylands v. Fletcher, by Prof. Francis H. Bohlen, U. of P. Law Review and American Law Register, Vol. 59 ,

Rutland Elec. Light Co. v. Marble City Elec. Light Co., 65

Vt. 377 ; 26 Atl. Rep. 635; 27 L. R. A. 821; 4 Am. Elec. Cas. 256,

Rylands v. Fletcher, 3 H. L. C. 330 ,

$35,49,51,71$

S.

Simmins v. City of Toledo, 8 Ohio C. C. R. 535,

Smith v. Tele. Co., 2 Ohio C. C. R. 259, 
Spring Valley Water Co. v. San Francisco, 165 Fed. Rep.

\section{7,668 ,}

Stackpole v. Healey, 16 Mass. 33; 8 Am. Dec. 121n,

State v. Janesville Street Railway Co., 87 Wis. $72 ; 57 \mathrm{~N}$.

W. 970; 4 Am. Elec. Cas. 289,

State v. Proctor, 90 Mo. 334; 2 S. W. 472,

Story v. N. Y. E. R. R. Co., 90 N. Y. 122,

Street Railway v. Cumminsville, 14 Ohio 546,

Submarine Telegraph Co. v. Dickson, $15^{\circ}$ C. B. (N. S.) 75; 106 English Common Law Reps.,

T.

Taggart v. Newport Street Railway Co., 16 R. I. 668; 19 Atlantic 326,

Telephone Co. v. Railway Co., 3 Am. Elec. Cas. 350,

Third Avenue Railway v. Newton, 112 N. Y. 396; 19 N. E. 831 ,

Townsend v. Norfolk Railway Light Co., 105 Va. 22; 4 L. R.

A. (N. S.) 87 ,

Tracy v. Troy \& Lansingburgh R. R. Co., 54 Hun. 550; 3 Am. Elec. Cas. 227,

Transportation Co. v. Chicago, 99 U. S. 635,

W.

Western Union Telegraph Co. v. Champlain Elec. Light Co., 14 Cin. Law Bulletin 327,

Western Union Telegraph Co. v. Guernsey \& Scudder Elec. Light Co., 46 Mo. App. 120; 3 Am. Elec. Cas. 425,

Western Union Telegraph Co. v. Los Angeles Elec. Co., 6 Am. Elec. Cas. 202,

Western Union Telegraph Co. v. New York, 38 Fed. Rep. 552 ,

Western Union Telegraph Co. v. Rich, 19 Kans. 517,

Wettengel v. Allegheny County Light Co., 223 Pa. 79,

Willis v. Erie T. \& T. Co., 34 N. W. 337,

Wisconsin Telephone Co. v. City of Oshkosh, 62 Wis. 32; 21 N. W. 828; 1 Am. Elec. Cas. 687,

Wisconsin Telephone Co. v. Eau Claire Street Railway Co., 3 Am. Elec. Cas. 383, 



\section{PART I. \\ THE LAW RELATING TO \\ CONFLICTING USES OF \\ ELECTRICITY}

CHAPTER I.

LEGAL POSITION OF ELECTRICAL COMPANIES.

1. Franchise holders distinguished from citizens.

2. Conflicts in the exercise of franchises.

3. Scope of this inquiry.

4. Conflicting uses of Electricity.

5. Nature of franchises.

6. Fundamental principles.

6a. Telephone companies and telegraph companies, a burden upon the highway.

7. Telephone company is a telegraph company.

8. They must not interfere with public travel.

9. The English doctrine.

10. Street railways have no exclusive right to the highway.

11. The railway a dominant franchise.

\section{Franchise holders distinguished from citizens.}

The common law principle that no wrong should go unredressed is, in most cases, where the wrong is simply an injury wrought by one to his neighbor, of simple application. The origin of a blow, of an explosion, or of a collision is not usually difficult to trace. But the insidious progress of a decay wrought by the subtler natural agents harnessed by industry, creates problems, in which rights so overlap that one can scarcely say, whatever the conclusion reached by a court of law, that substantial justice 
has been done. A citizen, the embodiment of certain definite legal as well as natural rights, as citizen, must be reckoned with in an equally definite way, when some of those rights have been violated. As he steps out of his armor, however, secures concessions and, in common with others, begins to play with the energies left at his disposal by nature, he and his rivals become involved in situations, in which conflicting rights seem to baffle any equitable adjustment.

\section{Conflicts in the exercise of franchises.}

A corporation is authorized to propel railway cars by means of electricity, the current passes through the car into the rail and thence to the earth; it erters the framework of an office building, sets up an electrolytic action and the building is damaged. This is a problem of some difficulty. But, assuming electricity to be a dangerous agent, and an innocent person in the enjoyment of his property harmed by its escape, we might reasonably suppose that the courts would find some grounds of liability. But let the current of electricity remain in the street and interfere with the electric current in use by the telephone company, and the problem is of another sort. For the persons using the street are not citizens, but licensees, and each one holds his rights in subordination to those of the public, and the other licensees. In consequence, if the use made of the street by one public service corporation, injures the property placed there by another public service corporation, the injury being neither wanton nor the result of negligence, the question is no longer that of the use of dangerous agents, but of the relative importance of the franchises.

3. Scope of this inquiry.

The inquiry here proposed, is directed to an examina- 
tion of the respective rights and liabilities of electric railway companies, telegraph and telephone companies, gas and water companies, and electric light, heat and power companies under such circumstances. To keep the inquiry free from confusion it is necessary to premise that the rights and liabilities involved, do not depend upon the fact that the person through whom the injury is worked is or is not a corporation.

\section{Conflicting uses of electricity.}

What then, assuming the street railway, telegraph and telephone companies and electric light, heat and power companies to be in occupation of the same street or streets, are the conflicts that may arise? Certain facts are common to all of the legal scientific problems created by several users of electricity in a given territory.

Telephone and telegraph companies use on their lines low or moderate voltages and small quantities of current.

Electric light companies or electric railways transmitr ting power for the performance of useful work employ in general higher voltages and transmit considerably more current over their circuits than telegraph and telephone companies.

In figures, the telephone companies use about 24 to 48 volts; the telegraph companies about $\mathrm{r}_{50} \mathrm{O}$ volts; the trolley companies from 500 to $\mathrm{r}, \mathrm{OOO}$ volts; electric light companies from I Io to Io,O0o volts or more.

A higher pressure of electricity tends to influence all lower pressures in its immediate neighborhood; it has an inclination to overflow and raise the pressure on all wires of lower pressure within certain distances of it.

Telephone and telegraph companies can scarcely maintain their service in the vicinity of very powerful currents of electricity without the aid of special apparatus, while electric light or power companies using a low voltage are 
in a similar peril from companies using a very high voltage. These are typical problems.

\section{Nature of franchises.}

The principle upon which cases of conflicting rights must be worked out is that the parties have abandoned their position as citizens and have assumed an entirely new relationship, in order to conceive which, it is necessary to disencumber the mind of established notions of inherent rights and inviolable privileges.

A person, natural or artificial, who secures a concession from the government of a city or other municipality to occupy streets or other public property for the purpose of supplying some public want, a franchise in other words, enters upon a peculiar relationship which is dependent, not upon his status as a citizen, but upon the terms of his contract or license. It must be recognized further that the keenness of public wants varies. The need or desire for telephone service may or may not be greater than that for gas pipes or trolley service. Moreover, of necessity, concessions or franchises in the same streets are frequently, nay generally, granted to all three of the licensees under discussion, viz., telegraph, telephone, electric and trolley companies. It will be perceived readily enough that the remedy for an injury resulting to one licensee or holder of a franchise from the mere exercise of the franchise by another licensee is somewhat difficult to apply. But recalling that a corporation holding a franchise is not a citizen with inherent, indefeasible rights, but such only as grow out of the privilege granted him, (as to the exercise of the franchise) some approximation of the only result possible in cases of conflicting interests may be reached. 


\section{Fundamental principles.}

There are certain facts and principles which are universally true. Differences of opinion do not arise so much from doubt as to fundamental principles, but from the difficulty of determining in the case of conflicting franchises both acting lawfully, where natural equity cannot be thrown into the scales of justice without absolutely destroying legal principles. Let us examine first, the principles that hold true universally.

It must be premised first, that the street or highway is public property, the title to, and control over which, is vested in the municipality: and further that the parties or corporations whose conflicting interests are under discussion, are occupying the streets by license from the municipality; second, that the public highways have been dedicated for the purpose of public travel. A highway is a public road which every citizen has a right to use. ${ }^{1}$

A street railway company is granted a franchise in furtherance of the object for which the highway was dedicated-viz., to facilitate public travel. This proposition may be regarded as generally true. ${ }^{2}$

A necessary corollary of this principle is, that the construction and operation of a horse railway upon a street is only a new mode of using it. ${ }^{3}$

(1) Angell \& Durfee on Highways, 3rd Ed. Sec. 2; Stackpole v. Healy, 16 Mass. 33, 1819, 8 Am. Dec. 121n; Davis v. Smith, 130 Mass. 113, 1881; State v. Proctor, 90 Mo. 334, 1886. 2 S. W. 472; Elliott on Roads and Streets, 3rd Ed. Sec. 1.

(2) Street Railway v. Cumminsville, 14 Ohio, 546, 1863; People v. Kerr, 27 N. Y. 188, 1863; Hobart v. Milwaukee, etc., 27 Wis. 194, 1870; Hinehman v. Paterson Horse Railroad, 17 N. J. Eq. 75, 1864; Briggs v. Lewiston \& Auburn Horse R. R. Co. 79 Me. 363 ; 10 Atl. Rep. 47, 1887.

(3) Central Pennsylvania Telephone \& Supply Co. v. WilkesBarre \& Westside Railway Co., 11 Pa. C. C. 417; 4 Am. Elec. Cas., 260, 1892. 
A change in the method of propelling cars, as by substituting electricity for horses is simply an improvement in transportation, and imposes no more burden than horse cars. ${ }^{4}$

The operation of electric cars by the Sprague and Thomson-Houston systems is a lawful or permissible way of exercising that franchise. ${ }^{5}$

\section{6a. Telephone companies and telegraph companies a burden upon the highway.}

Telephone and telegraph companies are in a somewhat different position. They occupy the highways by virtue of a grant from the municipality, and the grant is almost universally coupled with a provision that the construction of their lines or exercise of their franchise shall not interfere with public use of the highway. It may in fact be considered as established that the presence of telephone and telegraph companies upon the streets is an actual burden upon the highway, and that they are not there by virtue of rights acquired under their original dedication. "The telephone franchise is an indivisible franchise and is subordinate in all respects to the rights of public travel."6

\section{A telephone company is a telegraph company.}

Finally a telephone company is a telegraph company. In England the question was settled as early as I880, in the case of Attorney General v. Edison Telephone Com-

(4) Mt. Adams \& Eden Park Incline, etc., Co. v. Howard Winslow, 3 Ohio C. C. R. 425; 2 Am. Elec. Cas., 262, 1888.

(5) Cumberland Telephone \& Telegraph Co. v. United Electric Railway Co., 42 Fed. Rep. 273; 12 L. R. A., 544; 3 Am. Elec. Cas., 408, 1890.

(6) Hudson River Telephone Co. v. Watervliet Turnpike \& Rwy. Co., 135 N. Y. 393, 1892; 32 N. E. 148; 17 L. R. A. 674; 4 Am. Elec. Cas. 275, 1892. 
pany of London. ${ }^{7}$ That case decided that under the Telegraph Company acts of 1863 and 1869 , the Edison Telephone was a telegraph within the meaning of those acts, although the telephone was not invented or contemplated in I869. It was also settled that a conversation through the telephone was a "message," or at all events, a thought or communication transmitted by telegraph and therefore a "telegram" within the meaning of this act, and that since the Edison Telephone Company made a profit out of the rents, conversations held by subscribers through their telephones, were infringements of the exclusive privilege to transmit telegrams granted to the Postmaster General by the act of 1869 , and within the exception mentioned in section 5 .

The same decision has been reached in various American jurisdictions. In the case of Wisconsin Telephone Company v. City of Oshkosh, ${ }^{8}$ it was decided that telephone companies, though not specifically mentioned in the law relating to telegraph companies, might be incorporated under that law. A telegraph, it has been held, is a term which means and includes any apparatus or adjustment of instrument for transmitting messages or other communications by means of electric currents and signals, and embraces the telephone. ${ }^{9}$. This case adds to the other decisions the principle that telegraphs and telephones are public vehicles of intelligence, and can make no discrimination in the use of them by the public. ${ }^{10}$

(7) Attorney-General v. Edison Telephone Co. of London, L. R. 6 Q. B. D. $244,1880$.

(8) Wisconsin Telephone Co. v. City of Oshkosh, 62 Wis. 32; 21 N. W. 17; 1 Am. Elec. Cas. 687, 1884.

(9) The Chesapeake \& Potomac Telephone Company v. Baltimore \& Ohio Telegraph Company, 66 Md. 399; 7 Atl. Rep. 809, 1886.

(10) The Chesapeake and Potomac Telephone Company v. 
It seems to have been settled also, that in ordinary acts of assembly, telephone companies have not the right of eminent domain over the private lands of individual owners merely by reason of the quasi-public nature of their franchises. ${ }^{11}$ It was held likewise in this case, following the Supreme Court of the United State in Richmond v. Southern Bell Telephone Company, ${ }^{12}$ that the telephone company is a telegraph company. The express terms of the act of assembly under which the last decision was reached, was a denial by the legislature of any right on the part of telephone or telegraph companies to obstruct public travel, the words of the statute being "the same shall not be so constructed as to incommode the public use of such roads, streets or highways, or injuriously interrupt the navigation of such waters."

\section{They must not interfere with public travel.}

The general principle applicable to the position of the telegraph and telephone companies with respect to the use of highways is that laid down in the case of Blanchard v. Western Union Telegraph Company, ${ }^{13}$ in which it was established that those navigating the public navigable streams for commercial purposes, have the primary and paramount right to it, and every interference with or obstruction of the navigation, or hindrance to the free passage of vessels is prima facie a nuisance, and under the facts of that case, it was decided that telegraph cables so

Baltimore \& Ohio Telegraph Company, 66 Md. 399; 7 Atl. Rep. 809, 1886.

(11) Pennsylvania Telephone Company v. Hoover, $24 \mathrm{~Pa}$ Super. Ct. 96, 1904.

(12) Richmond v. Southern Bell Telephone Co., 174 U. S. 761, 1899.

(13) Blanchard v. Western Union Telegraph Co., 60 N. Y. 510,1875 . 
laid or suspended in navigable waters as to catch upon the keels or to come in contact with vessels navigating the streams, are improperly placed and to be construed as a nuisance.

\section{The English doctrine.}

In England, however, it is held that injuries done to electric cables, telegraph or telephone, by a ship's anchor, form the basis of an action for damages. In the case of the Clara Killam, ${ }^{14}$ it was decided that the master of a ship, permitting damage to occur by the entanglement of the ship's anchor with the electrical cable was guilty of want of nautical skill and that the ship might be condemned in damages and costs. In the case of Submarine Telegraph Company v. Dickson, ${ }^{15}$ the plaintiffs owned a telegraph cable between England and France. The injuries for which the action in this case was brought occurred more than three miles from the English coast, and were caused by the lowering of the anchor. The doctrine announced was that masters of ships were presumed to be aware of the existence and situation of submarine cables, and that the duty was thereby cast upon all masters of ships to manage their vessels so carefully and skilfully as to avoid injuring such cables.

It is to be observed, that such subjects have received a much more minute regulation in England than they have in the United States, the respective rights and duties of ship owners, telegraph companies, street railway companies, \&c., being carefully defined by statute. Compensation is given by the Submarine Telegraph act of $188_{5}$, schedule, article $I$, to ship owners who can prove that

(14) The Clara Killam, 39 L. J. P. 50.

(15) Submarine Telegraph Co. v. Dickson, 15 C. B. (N. S.) [109 E. C. L. Rep.] 759, 1864. 
they have sacrificed an anchor in order to avoid injury to a submarine cable. It was held in the case of Agincourt Steamship Company v. Eastern Extension Telegraph Company, ${ }^{16}$ that this right to compensation included only the actual value of the anchor, \&c., but did not render the telegraph company liable to pay the damages resulting from such a sacrifice.

Finally the decision has been reached that the use of the highway for the purpose of erecting telegraph poles, is a new and additional burden upon the fee in the highway for which the owner of the highway is entitled to compensation. ${ }^{17}$

From these latter cases, we may derive the principle that telephone companies are telegraph companies; that when they make use of highways they must not interfere with public travel, on streams, or on roads or streets. As to streams, this is not true in England.

\section{Street railways have no exclusive right to the highway.}

As against this we have the counter principle that the street railway has not an exclusive right to the highway; that its rights, too, are subordinate to those of the public and that in the case of an elevated railroad at least, its occupation of the streets is also considered an additional burden upon the highway. So that we reach a reasonable equality, in the standing of the rival licensees, with some slight advantage in the ordinary street railway. ${ }^{18}$

(16) Agincourt Steamship Co. v. Eastern Extension Telegraph Co., 76 L. J. (K. B.) 884, 1907.

(17) Board of Trade Telegraph Company v. Barnett, 107 Ill. 507; 1 Am. Elec. Cas. 565, 1883.

(18) Transportation Co. v. Chicago, 99 U. S. 635, 1878; Hinchman v. Railroad Co., 17 N. J. Eq. 77, 1864; Easton v. Railroad Co., 24 N. J. Eq. 58, 1873; Railway Co. v. Heisel, 38 Mich. 62, 1878; Davis v. Mayor, 14 N. Y. 506, 1856. 
It must be understood that even the street railway has not the exclusive use of any portion of the street. It has merely the paramount right to use that portion of the street occupied by its tracks, but the public has the right to use the street including the part occupied by the track. ${ }^{19}$

If then disputes arise between rival licensees of the city streets, the disputing licensees are persons who have been permitted to use the streets of the city for an especial purpose and they enjoy that right in common with other grantees of similar rights. These rights in any case are subordinate to those of the public. The railway company's use must not conflict with that of public travel.

\section{The railway a dominant franchise.}

None the less, being in furtherance of the purpose for which the highway was dedicated, the railway franchise is the highest that can be granted for the use of the streets. Except as to the priority of the railway franchise all other franchises, such as that of the telephone, are in a similar position-their right is subordinate to that of public travel. Consequently, it would seem if the cables of the telephone company were so close to the surface of the street that the passage of trucks or other vehicles above them rendered the cables useless, the company's only remedy would be to place the cables beyond the reach of disturbance. $^{20}$

(19) Goldrick v. Union Railroad Co., 20 R. I. 128; 37 Atl. Rep. 635, 1897.

(20) Wisconsin Telephone Co. v. Eau Claire Street R. Co., 3 Am. Elec. Cas. 383, 1890. 
CHAPTER II.

CONFLICTS IN THE USE OF ELECTRICITY PRODUCED BY STREET RAILWAYS.

12. The operating and construction of a railway cannot be enjoined if lawful.

13. Summary of principles.

14. The kind of relief open to a telephone company.

15. The telephone apparatus must be efficient.

12. The operation and construction of a railway cannot be enjoined if lawful.

With the relative rights of the parties before us, let us now examine the facts of one of the leading cases in which the question of the liability of an electric railway company for damages to telephone apparatus resulting from the escape of its electric current into the earth, was considered. The question was passed upon and decided in New York by the Court of Appeals, in the case of Hudson River Telephone Company v. Watervliet Turnpike and Railway Company. ${ }^{21}$ In that case the facts were these :

The plaintiff, a telephone company, brought an action against the railway company to restrain the railway from operating its system by means of an electric motor, known as the single trolley method, in certain streets of the city of Albany, on the ground that it would cause great and irreparable injury to the plaintiff's telephone system and service. So far as priority in time was concerned, the telephone company was incorporated in 1883 , while the

(21) Hudson River Telephone Company v. Watervliet Turnpike \& Railway Company, 135 N. Y. 393; 32 N. E. 148; 17 L. R. A. 674; 4 Am. Elec. Cas. 275, 1892. 
defendant only secured the right to operate its road by electricity in 1889 , which was six years later. The defendant had originally been a turnpike company, which was subsequently authorized to construct and maintain railroad tracks on its turnpike road. In I889 the defendant was given permission by the councils of Albany to use a single trolley system of electrical propulsion, and sometime prior to the beginning of the action, had fitted up its road for operation by that method. The injuries to the plaintiff were that the powerful current of electricity used by the defendant escaped in part, and passed through the earth and other conductors and affected plaintiff's lines, so that its customers were annoyed with loud noises and the switch-board was affected when one of the defendant's cars passed near any of the plaintiff's wires. In consequence, the use of the plaintiff's telephones was rendered difficult and unsatisfactory, and at times impossible.

It was found, as a matter of fact, that there were two ways in which the interference of currents could be prevented. First. The plaintiff could prevent it by using a complete metallic circuit, at great expense. Second. The defendant could prevent it by substituting the double for the single trolley system.

It may be seen at once that the failure of the telephone company in its action might be forecast when the rights of the railway company are analyzed, for the telephone company sued to restrain the use of the single trolley system. The court began its inquiry by a consideration of the right of the defendant to make use of the single trolley system of electrical propulsion. It is evident that once it is admitted that this is a lawful use of the highway by the railway company, that the telephone company's right to prevent the use of this particular system must fail. 
The view taken by the court, however, of the defendant's rights is the most extreme one that can be conceived. It is said, (Opinion, page 404), "The history of plaintiff's franchise is instructive upon this point. It is an intruder in the public streets and not possessed of any property rights which a Court of Equity can be invoked to protect, if the canon of construction which it insists upon applying to the grant of the defendant's franchises, shall be allowed to prevail. It is incorporated under the Act of I848, providing for the formation of telegraph conpanies. At that time, and for 20 years afterwards, the art of telegraph, as known and practiced, did not include the transmission of human speech by means of the telephone over wires strung upon poles.

"It would be a narrow and illiberal construction of the statute to hold that the defendant was irrevocably bound by the choice of a motive power made in 1862 . It then selected the only practicable one, but the authority to employ others was not thereby exhausted. It was a continuing privilege and was intended to be potential whenever and as often as the means of public travel might be improved or facilitated by its exercise. Equally flexible was the power given to the common council of the city to impose such reasonable conditions upon the enjoyment by the defendant of the franchises of a street railway company as in their judgment the interests of the public seemed to require. Their authority, in this respect, was coincident in extent with the company's right of selection. They could limit the municipal assent to a railroad operated in a specified way, as they did by the ordinance of 1862 , and while that remained unmodified no other method could be lawfully used, and they could, by a subsequent ordinance, as in 1889 , authorize the necessary changes to be made in the equipment of the streets for the introduc- 
tion of electricity as a propelling force. This power is fairly inferable from the original act, and may also, perhaps, be deduced from the provisions of the city charter, which authorizes them to regulate the use of the streets by railways."

This case is clearly distinguishable from that of the Third Avenue Railway v. Newton, ${ }^{22}$ cited at length by plaintiff's counsel. There the railroad company had no express grant of legislative authority and the consent of the municipality was refused. It was attempted to override the local authorities and compel them by mandamus to give their approval to the opening and excavating of the streets for the purpose of substituting a subsurface mode of operation, when the granting of the permission plainly involved the exercise of judgment and discretion. It was held that under such circumstances the department of public works could not be coerced to act favorably upon the company's application. But the case is not authority for the broad proposition, for which the plaintiff contends, that where the right to select a motive power is expressly given and not limited, either as to time or kind, and a selection has been made with the approval of the city authorities, the company cannot subsequently adopt a new and better system of propulsion upon obtaining the municipal consent thereto.

"The defendant was not subject to the provisions of section I2 of the Street Surface Railroad Act of I884 (Ch. 252), as amended by chapter 53 I of the laws of I889, requiring the approval of the railroad commissioners and the consent of the owners of one-half in value of the property abutting upon the streets.

It had the right to make the change under the act of

(22) Third Avenue Railway v. Newton, 112 N. Y. 396; 19 N. E. 831, 1889. 
I862 upon obtaining the consent of the common council, and hence it is embraced within the saving clause contained in section 18 , which declares that the act of 1884 shall not interfere with, repeal, or invalidate any rights theretofore acquired under the laws of the State by any horse railway company, or affect or repeal any right of an existing street surface railroad company to construct, extend, operate and maintain its road in accordance with the terms and provisions of its charter and the acts amendatory thereof. Inchoate, as well as perfected rights are saved by such a provision. ${ }^{23}$

"The defendant's authority to use electric motors in the propulsion of its cars in the streets of Albany and to operate them by the single trolley system, cannot, therefore, be successfully questioned, and, unless actionable damage has resulted, or will result, to the plaintiff therefrom; its complaint was properly dismissed by the trial court.

"There is no question of prior equities involved. It is a matter of strict legal right. Neither priority of grant nor priority of occupation can avail either party. The plaintiff has a franchise which is entitled to protection, but the prime difficulty it encounters grows out of its subordinate character. It has been given and accepted upon the express conditions that it.shall not obstruct or interfere with the enjoyment by the defendant of its franchise. The plaintiff is not using the streets for one of the purposes to which they have been dedicated as public highways, while the defendant is occupying them in such a manner as to expedite public travel and promote the public use to which they were originally devoted. The condition contained in the plaintiff's grant would have been implied had it not been expressly named.

(23) N. Y. Cable Co. v. Meyer, etc., 104 N. Y. 1; 10 N. E. $332,1887$. 
"The primary and dominant purpose of a street is for public passage, and any appropriation of it by legislative sanction to other objects must be deemed to be in subordination to this use, unless a contrary intent is clearly expressed. The inconvenience or loss which others may suffer from the adoption of a mode of locomotion authorized by law, which is lawfully employed, and which does not destroy or impair the usefulness of a street as a public way, is not sufficient cause for a recovery, unless there is some statute which makes it actionable. A different rule prevails if there has been an encroachment upon private rights to the extent of an appropriation of private property, and it was upon this ground that the decision in the elevated railroad cases was placed. ${ }^{24}$

"It was there held that an abutting owner has an easement of light, air and access in the street in front of his premises, of which he cannot be lawfully deprived with. out compensation, by the erection and use of an elevated railway structure.

"But the plaintiff has no easement in the public streets. It is there by virtue of a legislative grant, revocable at the pleasure of the power which made it, constituting, while it continues, a valuable franchise, which is recognized as property in the fullest sense of the term. ${ }^{25}$ The plaintiff's title to this property is, however, encumbered by a condition which diminishes its value, and it cannot rightfully complain of the burden which it has voluntarily assumed. It is a part of its compact with the State that the maintenance of its lines of communication shall not prevent the adoption by the public of any safe, con-

(24) Story v. N. Y. E. R. R. Co., 90 N. Y. 122, 1882; Lahr v. Met. E. R. R. Co., 104 N. Y. 268; 10 N. E. 528, 1887. 692 .

(25) People, etc. v. O'Brien, 111 N. Y. 1, 1888; 18 N. E. 
venient, and expeditious mode of transit." That this is not the court's last word, however, is indicated in the paragraph quoted below :

"It seems to be indispensable to the successful prosecution of the plaintiff's business, that it should make use of an exceedingly weak and sensitive current of electricity. By a law of electric force, not clearly defined or understood, the transmission of a powerful current, such as the defendant must use to supply motion to its cars, along a line of wire parallel with and in close proximity to the plaintiff's wires, induces upon the latter an additional current, which renders the operation of the plaintiff's telephones at all times difficult and sometimes impracticable. It is found that this disturbance cannot be avoided by the defendant without a complete change of the system adopted, and the use of motors which are more expensive, more dangerous and less useful and efficient. It is obvious, that to require such change to be made would be to grant to the plaintiff, by a decree of the court, that which the legislature has expressly and intentionally withheld. But the plaintiff is exposed to another danger which deserves consideration. Its system of communication is only partially established in the public streets. Its telephones are located upon the premises of its subscribers and patrons, and at a central exchange, which is upon private propenty. Its instruments are connected by branch wires with the main wires suspended upon the poles in the streets. To render their respective plants available, both parties must have a return electric current, and both use the earth for that purpose. The plaintiff grounds its wires upon private property and, in many cases, connects them with the gas and water pipes, and, in this way, establishes and completes its required circuit.

"It is immaterial whether its wires are grounded upon 
its own property or that of others, who permit the plaintiff to so use their premises. Its possession as a licensee would be lawful while the license continues. The defendant allows the electric current used for the movement of its cars to escape or discharge, at least in part, directly from the rails into the ground, from whence it spreads or flows, by reason of the conductivity of the earth, upon plaintiff's grounded wires, and the most serious loss which the plaintiff sustains results from this cause, which is scientifically known as conduction. The defendant insists that it has an equal right with the plaintiff to make use of this property, or law of nature, in the conduct of its business, just as all are entitled to the common use of the air and the light of the heavens, which, in a certain sense, is undoubtedly true. But the defendant does something more. It does not leave the natural forces of matter free to act unaffected by any interference on its part. It generates and accumulates electricity in large and turbulent quantities, and then allows it to escape upon the premises occupied by the plaintiff to its damage.

"We are not prepared to hold that a person even in the prosecution of a lawful trade or business, upon his own land, can gather there by artificial means a natural element like electricity and discharge it in such volume that, owing to the conductive properties of the earth, it will be conveyed upon the grounds of his neighbor with such force and to such an extent as to break up his business, or impair the value of his property, and not be held responsible for the resulting injury. The possibilities of the manifold industrial and commercial uses to which electricity may eventually be adapted and which are even now foreshadowed by the achievements of science, are so great as to lead us to hesitate before declaring an exemption from liability in such a case. It is difficult to see how 
responsibility is diminished or avoided, because the actor is aided in the accomplishment of the result by a natural law. It is not the operation of the law to which the plaintiff objects, but the projection upon its premises by unnatural and artificial causes of an electric current in such a manner and with such intensity as to materially injure its property. It cannot be questioned that one has the right to accumulate water upon his own real property and use it for a motive power; but he cannot discharge it there in such quantities that, by the action of physical forces, it will inundate his neighbor's lands and destroy his property, and shield himself from liability by the plea that it was not his act, but an inexorable law of nature that caused the damage. Except where the franchise is to be exercised for the benefit of the public the corporate character of the aggressor can make no difference. The legislative authority is required to enable it to do business in its corporate form, but such authority carries with it no lawful right to do an act which would be a trespass, if done by a private person conducting a like business. If either collects for pleasure or profit the subtle and imperceptible electric fluid, there would seem to be no great hardship in imposing upon it, or him, the same duty which is exacted of the owner of the accumulated water power; that of providing an artificial conduit for the artificial product, if necessary to prevent injury to others.

"But the record before us does not require a determination of the question in this form. The use which the plaintiff is making of its grounded wires, is a part of its system of telephonic communication through the public streets, and a necessary component of the service it maintains there under the permission of the State and is subject to the condition that it shall not incommode the use of 
the streets by the public. It is one indivisible franchise and is in its entirety subservient to the lawful uses which may be made of these thoroughfares for public travel. In this respect no distinction can be made between the injuries resulting from induction and conduction."

\section{Summary of principles.}

Summarizing the results of these cases, and in particular the case last examined, this much may be accepted as established in legal controversies of this sort. The attempt to enjoin the construction and operation of a street railway, because of any inconvenience to other franchise holders produced by its mere operation, is hopeless. Nor can the holder of another franchise, such as the telephone, hope to recover the cost of remedying defective apparatus, and any telephone apparatus capable of being disturbed to any marked extent by induction must be classified as defective, so long as there exist insulating or isolating devices, such as the complete metallic circuit, or the noninductive circuit, that would protect the telephone or telegraph lines. This much may be taken as settled. The operation of the railway cannot be enjoined in such cases, nor can the railway be compelled to change from a single to a double trolley system.

\section{The kind of relief open to a telephone company.}

Inasmuch as the kind of relief sought is important, let us examine in full the bill filed in the case of the Railway Company against the Telegraph Association. ${ }^{26}$ The petition filed in that case was as follows:

"The plaintiff says that it is an association incorporated under the laws of Ohio, for the purpose of constructing,

(26) Railway Co. v. Telegraph Association, 48 Ohio, 390, $1891 ; 27$ N. E. 890. 
maintaining and operating telegraph and telephone lines in said State and elsewhere, and has its principal office and business in the city of Cincinnati, where it is now and has for more than ten years past been conducting a telephone business, by means of wires stretched upon poles law fully placed and maintained in the streets pursuant to the statutes made for that purpose, and under the direction of the authorities of said city.

"Said wires are connected with and terminate at the several 'exchanges' owned by the plaintiff in said city and vicinity.

"At the 'exchange' the wires are so arranged, by means of a device for that purpose, that any one of them can be immediately connected with any other. Each wire also terminates in the office, store, room, place of business or residence of some person, firm or company, a subscriber to this association paying an annual sum for the use of the telephone and the service in connection therewith. Each of such subscribers can, by the use of the telephone and other patented inventions of which the plaintiff is the sole licensee in the territory where it transacts business, immediately communicate with and speak to an operator in an 'exchange,' and said operator can, and if requested, does, forthwith connect such subscriber's wire with that of any other subscriber named, so that the two may converse directly with each other.

"Such communication is effected by means of a slight but continuous electric current passing over the wire from the speaker to the hearer, and unless interrupted or interfered with is easily and quickly made.

"Plaintiff says that many thousand such communications are daily made between persons in all parts of said city and in the county of Hamilton, that all the principal offices, business houses, newspaper offices; hotels, and 
other places of resort, and many residences in said county are thus connected together and brought into communication.

"Plaintiff says that it has over three thousand such subscribers in the city and vicinity, and that its lines also extend to and connect all the villages for many miles around said city, and hundreds of communications are daily made over the last named lines, for each of which a small sum is paid plaintiff by the person sending the same; that the whole constitutes a business of value to the plaintiff and important to the public.

"Plaintiff further says, that the defendant is a corporation under the laws of Ohio, engaged in the maintenance and operation of an inclined plane railway in the city of Cincinnati, and claims to own, and is now in possession of, the street railway tracks of what is generally known as the Mt. Auburn Street Railway, which, beginning at the corner of Fifth and Walnut streets, in said city, extends thence, by single track, on Fifth to Main street, thence on Main, by single track, to Court street, thence on Main, by double track, to Mulberry street, where it connects with said inclined plane railway, also extending from the north end of said inclined plane railway, by double track on Locust and Mason streets, Auburn avenue and Vine street, to the Carthage turnpike and the Zoological Garden; also on Court street, by single track, from Main to Walnut street, and on Walnut street, by single track, to Fifth street to place of beginning.

"But plaintiff says, that the said tracks were originally constructed by the parties through whom defendant claims, under alleged grants from the city of Cincinnati, which provided that 'No motive power except horses or mules shall be used on said tracks,' and the same have never been altered or amended in that respect, and the defendant has never acquired from the State of Ohio, or the 
city of Cincinnati, any right to erect and maintain poles or wires in the streets aforesaid, or to use electricity as a motive power for its cars.

"Plaintiff further says, that since the defendant came into possession of said street railway, it has, within six months last past, and without lawful authority so to do, caused a line of iron poles to be erected on each side of all streets where said tracks are situated as aforesaid, and placed upon the said poles large wires which it keeps constantly charged with powerful currents of electricity, generated by large steam engines and dynamos owned and operated by defendant for that purpose, by means whereof the cars upon all parts of the track aforesaid are run and operated from six o'clock in the morning until twelve o'clock at night of each and every day.

"Plaintiff further says that the defendant claims to have secured authority from the commissioners of Hamilton county to extend tracks along and upon the Carthage turnpike to be operated by electricity, as aforesaid from the existing tracks to the village of Carthage, and will place thereon poles and wires, and unless restrained by the order of this court will proceed to run and operate street cars thereon in the same manner that it is now running and operating them upon existing tracks.

"Plaintiff further says, that ever since defendant commenced the operation of its cars by electricity, it has caused, and is still causing great damage and injury to plaintiff, by creating electric currents and noise upon plaintiff's telephone wires, many of which are and have been for a period long prior to the use of electricity by defendant located upon each and all the streets aforesaid, and upon the Carthage turnpike. By reason of the proximity of the defendant's poles and wires to those of plaintiff, and of the powerful currents used by defendant, together 
with its mode of use and manner of construction, currents of electricity are transmitted to, or induced upon, the wires of plaintiff such as to render them useless for telephonic purposes.

"The noises produced by defendant's operations are loud and continuous, so as to prevent communication by telephone, and the connection of many of plaintiff's subscribers with the exchanges and with each other, has been thereby interrupted and broken up, and some of said subscribers have ordered their telephones removed and canceled subscriptions, while others have only been restrained from so doing by the representations of the plaintiff's officers that steps would be taken to induce or compel defendant to remedy the evil.

"Plaintiff has received, and is receiving a multitude of complaints from subscribers whose lines are affected by defendant's operation, and numerous notices that unless the difficulty is remedied the telephones of the complaining subscribers must be removed.

"Plaintiff further says, that as soon as the defendant began the operation of cars by electricity, and the consequent injury to its, plaintiff's, plant and business, defendant was notified thereof and requested to remedy the same, and has since been repeatedly urged to do so, but up to the present time has failed and refused to apply or attempt to apply any remedy, or take any steps to prevent the injury to plaintiff aforesaid, which plaintiff is informed and believes can be done by defendant without any great expenditure of money, and without giving up the use of electricity as a motive power for its cars.

"Plaintiff asserts that great injury has been caused, and great and irreparable injury will be caused to it, by the continued operation of cars by defendant, as it is now, and has been heretofore, operating the same. 
"The plaintiff's lines and telephones in the vicinity of said street railway will be rendered useless, the revenue received from the subscribers thereof cut off, and the business of the company greatly reduced.

"Wherefore the plaintiff prays that defendant be temporarily enjoined from constructing and operating an electric railway on the Carthage turnpike, of the sort that it is now using, or of any sort that will interfere with, or injure, plaintiff's lines or business. That, on final hearing, said injunction be made perpetual, and the defendant further restrained from operating any of its cars by means of electricity, in the manner it is now operating the same, or in any manner that may interfere with, or injure, plaintiff's business.

"That the damages already suffered by the plaintiff be assessed and ordered paid by the defendant, and for such other and further relief as the nature of the case, and equity, may require."

\section{The telephone apparatus must be efficient.}

It will be seen that in this case the relief sought was in a sense similar to that prayed for in the Watervleit case, because the defendant had been making use of the single trolley system. There is this fact to be noted, however. The defendant in its answer alleged that the telephone company could obtain complete protection by making use of the McCluer device, or the complete metallic circuit which has superseded the McCluer device, which would increase the efficiency of the telephone service.

The court consequently decided that if the operation of the street railway by electricity as a motive power tends to disturb the working of the telephone system, the remedy of the telephone company will be to readjust its meth- 
ods to meet the condition created by the introduction of electro motive power upon the street railway. ${ }^{27}$

The relief asked in this case, however, was reasonable, and as will be seen later, it has in certain cases, been granted.

In connection with this fact, it may be taken as practically an established principle of law in its present state of development that under all similar conditions the McCluer device or the complete metallic circuit must be regarded as a necessary part of a properly equipped telephone apparatus, and therefore, a telephone company which has not taken every possible means to render its position impregnable, such as the use of the McCluer device or the complete metallic circuit will have no standing to enjoin the operation of a street railway, provided, of course, this operation is lawful. Otherwise the principle that telegraph companies occupy a secondary and subordinate position upon city streets is established by decisions in practically all of the States. ${ }^{28}$

(27) Railway Co. v. Telegraph Assn., 48 Ohio, 390; $27 \mathrm{~N}$. E. $890 ; 12$ L. R. A. $534,1891$.

(28) Smith v. Tel. Co., 2 Ohio, C. C. R. 259, 1887; Mt. Adams \& Eden Park Inclined Rwy. v. Winslow et al., 3 Ohio C. Ct. Rep. 425; 2 Am. Elec. Cas. 262, 1888; Blanchard v. The Western Union Telegraph Co., 60 N. Y. 510; 1 Am. Elec. Cas. 176, 1875; Board of Trade Tel. Co. v. Barnett, 107 Ills. 507; 1 Am. Elec. Cas. 565, 1883; Willis v. Erie T. \& T. Co., 34 N. W. 337, 1887. 


\section{CHAPTER III.}

AGAINST WHAT, RELIEF MAY BE GRANTED.

16. A railway company not protected in aggression.

17. Acts constituting a nuisance may be resirained.

18. Principles established in the case of Hudson, etc., v. Watervliet Turnpike Company.

19. The principles sound in view of the relicf sought.

20. Franchise holders may not encroach upon private property.

21. They must use the most efficient means at their command.

22. What are efficient means?

23. No exclusive right to use the earth as a return circuit.

24. Interference with submarine cables.

25. Defective construction of a railway must be remedied.

16. A railway company not protected in aggression.

This, however, does not mean that the railway company is ever protected in aggression; nor has the question of the relative rights of the parties been determined where both are using the most efficient known devices, and the railway is the aggressor. Another question that has not been considered apparently in relation to these decisions is the fact that steam roads and the like have been restrained from operation on the ground that the discharge of soot, smoke, cinders, etc., was a nuisance for which increased facility of travel did not compensate.

\section{Acts constituting a nuisance may be restrained.}

There are reactions in the law against the ancient principle that acts done under legislative sanction cannot be restrained, even where they amount to a nuisance. Thus in the case of Cogswell v. The New York, New Haven \& Hantford Railway Company, ${ }^{29}$ it was questioned whether

(29) Cogswell v. The New York, New Haven \& Hartford Railway Company, 103 N. Y. 10; 8 N. E. 537, 1886. 
the legislature can authorize a railroad corporation to maintain an engine house under circumstances, which, if maintained by an individual would, by the common law, constitute a nuisance to private property without providing compensation. And the erection of the engine house of an elevated railroad was restrained in that case as being a nuisance, the direct offense being the discharge of soot, cinders and the like. This is a contradiction of the doctrine of cases like Rhodes v. Dunbar, ${ }^{30}$ in which such nuisances have been held to be the necessary accompaniment of civilization and city life. This seems to be the rational course for the law to take. The principle that progress must be accompanied by an invasion of lesser rights for the general good, is a utilitarian precept that has always rested upon a doubtful foundation, and renders him who asserts it liable to become the prey of some later and stronger interest who can make an effective appeal to the same principle.

\section{Principles established in the case of Hudson, etc. $\nabla$. Wat-} ervliet Turnpike Co.

The referee appointed to try the Watervliet case, found,

I. That interference of currents could be prevented by the telephone company, by using a complete metallic circuit, which would entail great expense and interference with the business.

2. Interference could be prevented by the railway company by substituting the double for the single trolley system, or by using the storage battery system, which would entail less expense than the method first named.

The court as has been seen, refused to place any restrictions upon the use by the railway company of its franchises; a decision practically that whatever change of

(30) Rhodes v. Dunbar, 57 Pa. 274, 1868. 
apparatus was necessary to eliminate the inconvenience resulting from the operation of the railway must be made by the telephone company. This, in subsequent cases has been modified to this extent. If the injury caused by the operation of an electric railway is sufficiently great to produce a nuisance, while the court will not place any restrictions upon the use of the franchise, and will not dictate to the holder of the franchise the steps it must take to remedy the condition, it will nevertheless compel the offending corporation to take such steps as are necessary to abate the nuisance. This is the attitude adopted by the courts where the injury is due to electrolysis, which will be discussed later.

In reaching its conclusion the court, in the Watervliet case, used this reasoning:

r. A person aggrieved by the exercise of a franchise for the public benefit may be without remedy if the damage sustained be the result of the proper exercise of the franchise.

2. The use of electricity as a motive power for cars is a proper exercise of a railway franchise.

3. Priority of grant to the railway or to the telephone company is of no importance to either side of the controversy.

4. The franchise of the telephone company is subordinate to that of the railway company.

5. The inconvenience or loss which others may suffer from the adoption of a mode of locomotion authorized by law and skillfully applied, is not actionable.

6. A telephone company has no easement in the streets, but simply a franchise subject to the condition that it shall not prevent the adoption by the public of any safe, convenient and expeditious mode of transit. 
7. The burden of changing the system if any be needed, is upon the telephone company.

19. The principles sound in view of the relief sought.

Admitting that the relations of the parties are those above stated, it seems difficult to reach any other conclusion. A franchise does not give the holder of it any easement in the streets and while it is property, it is property subject to certain conditions that not only hedge its existence, but may even destroy it.

20. Franchise holders may not encroach upon private property.

While the courts have gone very far in granting immunity to holders of franchises for injury resulting from their operation, it is generally conceded that there must be no direct encroachment upon private property. In the case of Transportation Company v. Chicago, ${ }^{31}$ the decision was reached that a thing authorized by the law cannot be a nuisance such as to give a common law remedy. The principle involved is an important one, since it closes the avenue to the so frequently invoked fourteenth amendment to the Constitution of the United States, so that a telephone or other electric company cannot claim that its property has been taken without due process of law if its currents of electricity have been interfered with. The doctrine in this particular case agrees with the English viewpoint. Acts done in the proper exercise of governmental powers, and not directly encroaching upon private property, although their consequence may impair its use, are not a taking within the meaning of the Constitutional provision, which forbids the taking of such property for public use without just compensation therefor. The principle established by this case and by decisions practically

(31) Transportation Company v. Chicago, 99 U. S. 635, 1878. 
uniform throughout the United States, is that work which is authorized by law cannot be a nuisance. ${ }^{32}$

It is clear, therefore, that in order for injuries occasioned by the exercise of a franchise to justify an injunction there must either be an improper use of the franchise or some abuse of the power granted by the legislature. If the company constructs its road in accordance with proper methods, within the powers granted, it seems that in the absence of direct aggression the law affords no remedy. The sole requisites of the immunity of the person exercising the franchise are that the work be executed in an authorized manner and in an authorized place. $^{33}$

21. They must use the most efficient means at their command.

One necessary premise of this conclusion is, however, that both parties are using the most efficient means at their command, in the exercise of their respective franchises. If it is at all possible, it would seem that both parties are bound to construct their plant in such a manner as not to impair the exercise of other franchise holders. If the telephone apparatus is so delicately constructed that slight disturbances will impair its usefulness, then the remedy lies at the doors of the telephone company. It must adopt means to protect its apparatus from injury. ${ }^{34}$

22. What are efficient means?

The necessary conclusions from the cases thus far ex-

(32) Hinchman v. The Paterson Horse Railway Company, 17 N. J. Equity 75, 1864.

(33) Easton v. N. Y. \& Long Branch Railway Company, 24 N. J. Equity 49, 1873.

(34) Eastern \& South African Telegraph Co. v. Cape Town Tramways Companies, L. R. App. Cas. (1902) 381. 
amined seem to be (I) That as to all new telephone or other electric franchises, the use of a metallic circuit to protect the lines from interference by trolley or other high voltages of electricity, is a necessary part of a properly equipped apparatus. (2) That an electric railway using the ordinary single trolley system, now in general use, is making use of a properly equipped apparatus.

\section{No exclusive right to use the earth as a return circuit.}

The solution of the problem has been attempted on a different ground, viz.- That the company first gaining the right to use the earth as a return circuit, thereby necessarily acquires the power to inhibit such a use of the earth to all subsequent licensees of the street. A telephone company filed a bill in equity to enjoin the use of electricity by the street railways of Nashville under any system which makes use of the earth for its return circuit. The facts upon which the right to maintain such a contention was based, are these. The telephone company was organized and given a franchise in the streets in Nashville, in 1879 , about eight years prior to the use of electricity by the street railways of Nashville; it had some fourteen hundred subscribers; its service was rendered inefficient by the operation of the trolley cars, by means of the Sprague system, in that by conduction strong currents of electricity entered into the telephone cables, and that by induction, varying currents were produced on the telephone wires; the injury to the telephone service could be eliminated by the use of a double trolley system. In reply, the railway company stated that its cars were operated by electricity and that they transported I 5,000 persons daily; that the single trolley system was practically the only one that had stood the test of experience; that the telephone company was not entitled to a monopoly of the 
earth as a return circuit; and that the telephone company could remove the difficulty either by using a complete metallic circuit or a device known as the "McCluer Device." The injunction was denied, the court relying upon principles differing somewhat from those laid down in the case first discussed. It was established as a fundamental proposition first, that nothing which is authorized by competent authority can be treated as a nuisance per se. Further, that, so far as persons operating under legislative grants were concerned, something more than mere incidental damage to another must be proved-something, in fact, in the nature of an abuse of the franchise-to entitle the party injured to an injunction. The injunction was refused for the reasons:

I. That the defendants are making a lawful use of the franchise conferred upon them by the State, in a manner contemplated by the statute, and that such act cannot be considered as a nuisance in itself.

2. That, in the exercise of such franchise, no negligence has been shown, and no wanton or unnecessary disregard of the rights of the complainant.

3. That the damages occasioned to the complainant are not the direct consequences of the construction of the defendant's roads, but are incidental damages resulting from their operation, and are not recoverable.

4. The telephone has not a monopoly of the use of the earth for its return currents. ${ }^{35}$

24. Interference with submarine cables.

While the right of a street railway company to discharge electricity into the street depends, as to the holder

(35) Cumberland Telephone \& Telegraph Co. v. United Electric Railway, 42 Fed. Rep. 273; 12 L. R. A. 544; 3 Am. Elec. Cas. 408, 1890. 
of another franchise in the street, upon its superior right, it would seem difficult to extend the principle so as to permit the railway company to interfere with the operation of public undertakings. Such a conclusion has been reached, however. The electricity which passed into the earth from a trolley line entered the submarine cable operated by the Eastern and Southern Africa Telegraph Company, and rendered it useless during the passing of cars. It will be seen that the relative position of the two companies differed from those previously discussed. The relative value of the two franchises can scarcely be measured, since the telegraph cable was one connecting Europe with Cape Town, and the relative value of trolley service and communication with the outside world is somewhat difficult to estimate, and moreover the two companies do not hold similar franchises nor franchises in the same street. A question of conflict of franchises therefore does not arise. It is rather a question of liability of the railway company for injury done to private property by the escape of the dangerous agent of which it makes use. And this liability seems generally conceded. ${ }^{36}$ If change in the system of the telegraph company became imperative the railway company ought to bear the cost. But as no irreparable injury appears, as the situation may be remedied by a change of apparatus, an injunction it seems would not lie, and the court refused to grant it. It went further, however, and refused to award damages to the telegraph company. The principle of Rylands v. Fletcher, seems clearly to apply and the court did apply it, but considered the present case an exception. "The principle of Rylands v. Fletcher," 37 it was said, "applies to a pro-

(36) Lahr v. Met. E. R. R. Co., 104 N. Y. 268; 10 N. E. 528, 1887.

(37) Rylands v. Fletcher, L. R. 3 H. L. C. 330, 1868. 
prietor who stores electricity on his own land if it escapes therefrom and injures a person or the ordinary use of property. It does not apply to the case of injury done to a peculiar trade apparatus unnecessarily so constructed as to be affected by minute currents of the escaping force."38

To return for a moment to the use of the earth to complete the circuit, it is clear that no person can prevent another from making such a use of it. When the discovery was made in 1838 , that it was practicable to use the earth for the return of the electric current, an application was made for a patent upon the discovery, and it was refused. As a matter of common knowledge it was open to the use of anyone who could apply it to his purpose. But the expansion of steam and its capacity for doing work is also known, and yet the user of it is very nearly an insurer of the safety of those within range of its destructive possibility, since it increases the degree of care required of him. The principle applied in the case last considered, of injuries to a submarine cable would seem to leave no redress for anyone injured by the escape of the electric current wherever absolute negligence could not be proved. If the electricity passing into the earth from a trolley car by conduction entered the metal framework of an office building, which was in danger of destruction, it would be an answer to say that the building was unnecessarily built so as to be susceptible to destruction by electricity and that the owner should remodel his building on the reinforced concrete system or on some plan not involving the use of substances which electricity might attack. This does not sound convincing. The true rule in such cases must be not destruction of the franchises but placing the burden

(38) Eastern \& South African Telegraph Co. v. Cape Town Tramways Companies, L. R. App. Cas. (1903) 381. 
of change, where the parties have equal rights, upon the one making it necessary. This point has now become academic by reason of the decisions upon electrolysis.

\section{Defective construction of railway must be remedied.}

There is no doubt that a railway company is bound to adopt all ordinary and usual appliances and methods to prevent contact between its trolley and the feed wires of a telephone company stretched along or across the same highway, and defective construction is good ground for restraining the operation of the trolley line. ${ }^{39}$

But if no defect of construction appear, and the situation require an adjustment of the lines in such a way as to avoid conflict of the franchises, the adjustment must be made by the telephone company, and it must raise or lower its lines wherever necessary. The courts have even gone so far as to say that if it should be impossible to construct and operate a telephone line and an electric railway on the same street at the same time, it is doubtful whether the telephone company has the superior right to the use of the street, merely because its use was prior in time. $^{40}$

This is surely open to question. It is, however, as futile a question as the old problem of the immovable mass, struck by an irresistible force. The true answer to such a problem, beyond all question is, that if the use of both franchises on the same street be impossible, it is the duty of the invading railway company to bear all expense necessary to render both franchises possible.

(39) Central Penna. Telephone Co. v. Wilkes-Barre \& West Side Railway Company, 11 Pa. C. C. 417; 4 Am. Elec. Cas. 260, 1892.

(40) Central Pa. Tel. Co. v. Wilkes-Barre, etc., Ry. Co., 11 Pa. C. C. $417 ; 4$ Am. Elec. Cas. 260, 1892. 
For, let us assume a telephone company, already in existence, having laid its lines on a street into which an electric railway enters. The telephone company has its cables, its apparatus, its buildings. The railway company begins operations and makes it impossible for the telephone lines to be operated no matter how constructed. Can it be contended that the telephone company is not a property holder, whose property has been taken without due process of law? In such a case, if the invading company makes it necessary to change the location of the telephone lines, the burden should be borne by the invader. 


\section{CHAPTER IV.}

\section{INJUNCTIONS AND OTHER REMEDIES.}

26. Invasion by a new franchise holder enjoinable.

27. Direct interference by a railway may be restrained.

28. Railway may be compelled to orect guards.

29. Injury due to lawful operation distinct from aggression.

30. Accommodation of conflicting franchises.

31. First franchise on given territory not exclusive.

32. Ordinances requiring guard wires.

33. Principle of dominant use of highway. Application.

\section{Invasion by a new franchise holder enjoinable.}

Such a conclusion has been reached where an electric light company has sought to place its wires so close to the lines of a telegraph company, that the telegraph lines became useless.

The electric light company had a contract to supply the city with light while the telegraph company was already in the field. The relief sought by the telegraph company was extreme, as it attempted to exclude the electric light company from occupying the same side of the street as itself. The court granted the relief only to the extent of preventing the electric light company from placing its wires so close as to interfere with the operations of the telegraph company by induction or to endanger the lives of its linemen, when they might have occasion to ascend the poles. We may draw this conclusion as a principle involved in similar cases. The right of the company assailed is only to protection against actual or threatened injury. It is not entitled to hold its franchise to the exclusion of all newcomers, on proof merely of additional inconvenience in the operation of its plant. ${ }^{41}$

(41) Western Union Telegraph Co. v. Chaplain Electric Light Co., 14 Cin. Law Bulletin 327, 1885. 
In a certain sense, a corporation occupying a portion of the city streets with its equipment by virtue of a license or franchise from the municipality, is a landowner. Its right of occupancy is a property right that will be as much protected from unlawful invasion as any other property right. ${ }^{42}$

The telephone company having its right invaded by a street car company is therefore to some extent a landowner whose property has been injured by a dangerous agent escaping from the property of his neighbor.

The street railway's right to invade the telephone or telegraph franchise narrows itself then, to this, that the telephone company cannot acquire a vested right to use the earth as a medium for the return of its current; or in other words, there is no monopoly in the earth; but it is entitled to protection against unlawful invasion.

\section{Direct interference by a railway may be restrained.}

If the railway company's trespass be direct interference with the telephone company's service, the law gives the latter a remedy. If the wires touch the telephone wires, cross them, ground them and prevent the subscribers from using them, it is ground for an injunction.

The court in this case, affirmed the general principle that to entitle a telephone company to enjoin an electric railway company from operating a line, under a legislative grant, on a street occupied by the former, damages in the nature of an abuse of the franchise, and not mere incidental damages must be proved. But the real test, as suggested by the court, of what is an abuse of the railway franchise is the answer to the question, "Can the

(42) Chicago v. Baer, 41 Ills. 306, 1866; Rich v. Chicago, 152 Ills., 18; 38 N. E. 255, 1894; Lake St. Elec. Railway Co. v. Chicago, 183 Ills. 75; 55 N. E. 721, 1899. 
damage be avoided by a proper construction of the railway line?" If the answer is yes, the remedy exists, and the railway company may be enjoined. The action of the railway company in such a case is not a lawful exercise of its own franchise, but is a usurpation of the telephone franchise.

The facts of the case under discussion, it is true, present an aggravated case of usurpation. For, it appeared, that the complainant, before filing his bill, went to see the general manager of the railway company, and called his attention to the fact that the railway company was constructing its poles and wires in such a way as to prevent the telephone company from carrying on its business and that the manager replied in emphatic language that the railway company would not correct the abuses complained of, and notified the telephone company that if it did not itself correct these troubles, the railway company would tear up the telephone wires and poles.

The court regarded this as proof of an unwarranted usurpation of right and power by the railway company, denying to the telephone company anything like an equal privilege to the enjoyment of the streets with the defendant.

It may be said in passing that such injudicious remarks of officials of either company stamp the act of the company at once as arbitrary and unmindful of the rights of others, which militate strongly against the offender in a court of equity where the majority of these controversies are tried, equity demanding that the parties seeking equity must do equity. ${ }^{43}$

\section{Railway may be compelled to erect guards.}

The apparent unfairness that may result from the ap-

(43) Birmingham Traction Co. v. Southern Bell Telephone Co., 119 Ala. 144; 24 So. 731, 1898. 
plication of the doctrine that injury resulting from the operation of an electric franchise is damnum absque injuria (not actionable) has called forth a protest from the Missouri courts. That court has declared expressly that it did not share the extreme views of other courts, and that it was the duty of the public and of the individual to prevent a nuisance; the fact therefore, that the person injured by the nuisance could prevent damage by changing his plant or his apparatus at little or at much expense, is no answer. The fact remains that the other party is an aggressor and the expense of making the change should be borne by him. The electric company at suit of the telephone company was compelled to put a guard under its high voltage wires, and to keep its wires at least eight feet distant from those of the telephone company. And the remedy it was held, exists at law or in equity. ${ }^{44}$

\section{Injury due to lawful operation distinct from aggression.}

The cases fall into a distinct line of cleavage at this point. There is a distinction between injury due to the ordinary operation of an electric railway, because of the escape of electricity from the rails, and cases of direct aggression, where an invading electric company places wires of high voltage unguarded, and unnecessarily near those of another company using a lower voltage, and certain to be influenced by the stronger current. We may observe, therefore, that an invading company will never be permitted to come so close with its apparatus to the established company as to do harm, but that harm merely incidental to the valid exercise of a lawful franchise is not the basis of an action. ${ }^{45}$

(44) Western Union Telegraph Co. v. Guernsey \& Scudder Elec. Light Co., 46 Mo. App. 120; 3 Am. Elec. Cảs. 425, 1891.

(45) Western Union Telegraph Co. v. Guernsey \& Scudder 


\section{Accommodation of conflicting franchises.}

Since the efforts of the courts should be to accommodate both franchises so as to enable both to exercise their corporate rights, the mere presence of both companies on the same street is not sufficient to justify the first company in an effort to exclude the second. Where difficulty and conflict could be avoided by having the wires of the second company placed twenty-five feet above those of the first, the court decided that the first company was not entitled to an injunction. ${ }^{46}$

\section{First franchise on given territory not exclusive.}

The right of the first holder, it was said, is not absolutely exclusive. It is subject to such incidents as result from the exercise of the rights of other parties who have acquired a valid franchise of similar character. It is implied in such grants as were here made to the first company that the grant is subject to such limitations as will enable another company to enjoy a like franchise, and no property right is invaded by the adoption of such measures by the second company as will enable it to exercise its privilege, provided there is no unreasonable and unnecessary invasion of the operations of the first occupant. For the property right of the first is not to a monopoly.

The court said by way of modification, "It is not intended, of course, to say that the first occupant may be despoiled, or the substance of its right appropriated. But this does not happen from merely giving place to a rival

Electric Light Co., 46 Mo. App. 120; 3 Am. Elec. Cas. 425, 1891 ; Cumberland Telephone \& Telegraph Co. v. United Electric Railway Co., 42 Fed. Rep. 273; 12 L. R. A. 544; 3 Am. Elec. Cas. 408, 1890.

(46) Louisville Home Telephone Company v. Cumberland Telephone \& Telegraph Co., 111 Fed. Rep. 663, 1901, reversing 110 Fed. Rep. 593. 
company, whose presence was expressly stipulated for by the contract, nor probably, if the presence of the new party was the result of the exercise of a power reserved by implication in such a grant of privileges. The distinction between the actual invasion of the property of a former licensee engaged in supplying public utilities, and those incidental consequences which result from the authorized exercise of the privileges granted to a subsequent licensee for similar purposes was pointed out in an elaborate opinion by Mr. Justice Brown, now a justice of the Supreme Court, in Cumberland Telephone and Telegraph Co. v. United Electric Railway Company. ${ }^{47}$

But it is to be noted that some at least of the conclusions reached in Cumberland Telephone and Telegraph Company v. United Electric Railway Company, have been shaken in the case of Peoria Water Works Company v. Peoria Railway Company. ${ }^{48}$

\section{Ordinances requiring guard wires.}

Carrying this principle farther, the telephone company aware of the fact that the railway company has not provided guard wires, should have the right to compel the erection of such wires by mandamus. And this decision has been reached where a municipal ordinance required the maintenance of guard wires by "an electric railway company whenever it should be necessary to cross telephone lines." 49 As a constitutional question it has been set-

(47) Cumberland Telephone \& Telegraph Co. v. United Electric Railway Company, 42 Fed. Rep. 273; 12 L. R. A. 544; 3 Am. Elec. Cas. 408, 1890.

(48) Peoria Waterworks Co. v. Peoria Railway Company, 181 Fed. Rep. 990, at p. 1004.

(49) State v. Janesville Street Railway Co., 87 Wis. 72; 57 N. W. 970; 4 Am. Elec. Cas. 289, 1894. 
tled that such an ordinance applies to crossings previously in existence. ${ }^{50}$

"We are of the opinion that the facts set out in the relation are sufficient to entitle the relator company to the remedy asked for: (I) The telephone company occupied the streets of the city with its poles and wires, and was in the safe and successful prosecution of its business, under the authority of law and "by the permission, consent, and approval" of the city of Jonesville. (2) The defendant company afterwards sets its poles and extends its wires along the same streets, so that its lines frequently cross the lines of the relator, and in such near contact as to endanger the persons in its employment, and its property, and threaten the destruction of its business. Has the defendant the right to do this, if it is in its power to prevent the threatened mischief? By the common maxim that one person has no right to use his own to the injury of another, and by the common principles of elementary law, it would seem that it had not. The defendant has intruded upon the established business of the relator in such a way as to endanger it and the persons engaged in it, when, by the adoption of such a simple safeguard and the only practicable one, such danger can be avoided and the business of both subsist together. Ought not the defendant to be compelled to adopt such safeguard? These facts are admitted by the demurrer. The learned counsel of the respondent insists that the relator had not such priority of its business by any right. It is averred in the relation that it was established according to law and prosecuted "by the permission, consent and approval" of the city. That would clearly give the relator a right, and that right and its enjoyment were prior to any right of

(50) State v. Janesville Street Railway Co., 87 Wis. $72 ; 57$ N. W. 970; 4 Am. Elec. Cas. 289, 1894. 
the defendant. The relator's wires are up in the streets, bearing sufficient electrical power to make telephonic communications, and the defendant crosses them in many places with its wires, bearing electrical power sufficient to propel the cars upon its street railway, and the first storm that comes may blow down the poles and wires of the relator, and its wires come in contact with the wires of the defendant, where they cross each other, and become charged with its dangerous currents of electricity, set fire to the buildings in which the telephone instruments are used, and injure other property and the persons employed in the "exchange" and other places, so as to endanger or destroy the business of the relator. Ought not the defendant to be compelled to adopt the above safeguards to prevent this threatened mischief, or to withdraw its lines from the vicinity of the relator's wires? The company that caused the mischief ought to repair it.

"Sec. 7 of the ordinance of the city dated October Io, I892, imposes this duty upon the company using this "electrical power system" in all cases, and requires it to apply such safeguards under a penalty. But much more is it the duty of such company when it is an intruder upon the already established business of another company. The electric force is the most powerful and dangerous agency of nature, and, even when restrained or controlled by the most perfect machinery and appliances, its high tension currents are extremely dangerous in many directions. If a municipal corporation has not the inherent provisional or police power to pass ordinances to regulate or restrain the use of such a dangerous agency within the corporate limits, it certainly cannot have such power for any purpose.

"It is claimed that said ordinance has only future operation or effect. In application to the case, Sec. 7 of the 
said ordinance provided: 'Whenever it shall be necessary to cross. . . . telephone line or lines of any wires used,' etc. Has it not been necessary for the defendant company to cross these telephone lines or wires of the relator since the passage of the ordinance, and is it not now necessary to do so? Then the ordinance, by its terms, is applicable to this case. The ordinance is made to regulate existing things, and things which continue to exist, as the wires of the defendant cross the wires of the relator. Whenever, at any time, wires so cross, this safeguard must be applied. The ordinance has a present and future effect. It is said these wires crossed before the ordinance was passed. That is true, and they have continued to cross ever since, in violation of the ordinance. The ordinance does not prohibit the crossing of such wires. It provides the remedy for it as an existing evil, and requires safeguards to be so placed as to avoid the danger to persons and property. It is not retroactive in any sense.

"First. The ordinance is reasonable, because it requires that to be done which in law and good conscience the defendant ought to do for the protection of the relator, whose established business it has endangered and disturbed. Second. It is clearly sustained under the police power of the city. 'The test is whether it is designed and tends to protect some public or private right from the injurious act of the company; as when it prohibits the running of the cars of one company on any street so near the depot of another railroad as to interfere with safe and convenient access to the latter road.' Tied. Lim. 597599. The statute of New York, requiring telegraph, telephone, and electric wires to be placed underground in streets in certain cities (ch. 499, Laws of I885), was up- 
held in People ex rel. N. Y. E. L. Co. v. Squire, ${ }^{51}$ and Western Union Telegraph Company v. New York." 52

\section{Principle of dominant use of highway. Application.}

The principle that the dominant use of streets is that of the public for travel applies not only to modes of travel in use when the telephone is placed in the highway, but any future ones that the progress of science may introduce. The telephone company has no ground of complaint arising from such circumstances. ${ }^{53}$ It is powerless, therefore, to enjoin the operation of an electric road. ${ }^{54}$

This conclusion is almost inevitable from the propositions first settled as necessary a priori notions in all similar problems. All the parties are licensees from the municipality. The first license does not take all that the city, town, township or borough may have to give, but only a right subject to the city's or other municipality's power to grant a similar right for the same or for some other purpose, and this though the first licensee may suffer some inconvenience. ${ }^{55}$

(51) People ex rel. N. Y. E. L. Co. v. Squire, 107 N. Y. 593, $1888 ; 14$ N. E. 500.

(52) Western Union Telegraph Company v. New York, 38 Fed. Rep. 552, 1889.

(53) Wisconsin Telephone Co. v. Eau Claire Street Ry. Co., 3 Am. Elec. Cas. 383, 1890.

(54) East Tennessee Telephone Co. v. Knoxville Street Ry. Co., 3 Am. Elec. Cas. 400, 1890.

(55) Western Union Telegraph Co. v. Guernsey \& Scudder Electric Light Co., 46 Mo. App. 120, 1891. 


\section{CHAPTER V.}

ENGLISH AND CANADIAN DOCTRINES.

34. The English point of view.

35. Effect of English doctrine. Application to submarine cable.

36. Doctrine of statutory immunity.

37. Canadian authorities.

38. Private persons cannot restrain exercise of electric franchises.

34. The English point of view.

The English, American and Canadian cases upon the subject of conflicting uses of electricity have exercised a great deal of influence upon each other. The case of National Telephone Co. v. Baker, ${ }^{56}$ has been widely quioted and followed.

In that case, the telephone company, operating in the city of Leeds, was employing the "single wire" system, the earth being used as a return circuit. The defendant was a railway company authorized to construct a street railway in Leeds, but it was expressly stipulated that the operation of its lines should not cause harm to any telegraphic lines, by induction or otherwise. The railway company made use of the single trolley system. It was found that the operation of the railway system rendered the telephone lines useless, and an injunction was sought as for a nuisance. It was also in evidence that the disturbance to the telephone system could be obviated by the employment of a complete metallic circuit.

The court decided that the doctrines of Rylands $v$. Fletcher, ${ }^{57}$ applied, and that, if the situation of the par186.

(56) National Telephone Co. v. Baker, L. R. (1893) 2 Ch.

(57) Rylands v. Fletcher, 3 H. L. C. $330,1868$. 
ties had been equal in other respects, the plaintiff would have been entitled to an injunction. But, it was said, "the defendants are expressly authorized to use electrical power, and the legislature must be taken to have contemplated it, and to have condoned by anticipation any mischief arising from the reasonable use of such power." This phrase has been made the basis of many expressions of opinion in the American cases. The injunction was denied upon these grounds.

It must be noted that one element of fact which appeared in the case, was that the trolley system was operated in accord with a reasonably modern standard of efficiency, while the telephone company was using a system that could not even then be considered of a high order of efficiency.

\section{Effect of English doctrine. Application to submarine cable.}

But this much may be taken as settled by the English cases; electricity has been given a place with dangerous agents, which fall under the rule of Rylands v. Fletcher. Their use, in general, makes the user an insurer that no harm will result. In the case of Eastern and South African Telegraph Company v. Cape Town Tramways Company, ${ }^{58}$ the submarine cable of the telegraph company was rendered useless by the operation of the defendant's trolley cars. In this case also the statute authorizing the railway company provided "The company specially undertakes that, in the event of any electric leak taking place, and any damage thereby being caused at any time, by electrolysis or otherwise, it will reimburse and make good to the council or other body or person all costs, damages, and expenses to which the council or other body or per-

(58) Eastern and South African Telegraph Company v. Cape Town Tramways Company, L. R. App. Cas. (1903) 381. 
son may be put by reason thereof, and provided further that nothing in this act contained shall entitle the company to use the rails of the said lines of tramway as a part of its system of conductors for the return electrical current without the consent of the council first had and obtained."

It appeared that fully 30 per cent. of the current of the railway system escaped into the earth and sea and travelled along the sheathing of the submarine cable, rendering the cable useless. The telegraph company eliminated the injury by laying a twin core cable for several miles out, the two wires rectifying each other's action, and sued for the expense.

The court said that although the twin cable was not necessarily generally used and recognized, it demonstrated that the electric escape in question is not destructive of telephone communication generally, but only that it affects instruments made in a certain way.

It was decided finally, that the principle of Rylands v. Fletcher. ${ }^{59}$ imposes a liability on a proprietor which is measured by the non-natural use of his own property, not by that of his neighbor. It applies to a proprietor who stores electricity on his land if it escapes therefrom and injures a person or the ordinary use of property. It does not apply to the case of injury done by minute currents of the escaping force to a peculiar trade apparatus unnecessarily so constructed.

\section{Doctrine of statutory immunity.}

Giving to the proposition that the cable might or might not have been laid as a twin core cable, its fullest possible effect, it is difficult to follow the reasoning used in arriving at the decision. Half of the factors that should affect

(59) Rylands v. Fletcher, (1868) L. R. 3 H. L. C. 330. 
any conclusion reached in the case are ignored-the fact that the railway company took no precautions to prevent leakage, but left its rails in electrical contact with the earth; the fact that as high as 30 per cent. of the current escaped; the fact that the zone influenced by the trolley operations extended far out into the sea; the fact that the statute expressly placed a condition of liability on the use of the earth as a return circuit; the fact that the trolley company sought and regarded nothing but its own convenience, all are lightly passed over or ignored, and a recovery is denied. This case carries to the limit the doctrine of statutory immunity.

\section{Canadian authorities.}

The Canadian authorities are in substantial accord with the decisions reached in the United States. The statute of 34 Vict. C. $45^{\circ}$, authorized street railways to use motive power produced by steam, caloric, compressed air, or by any other means or machinery whatever. It has been settled that this statute confers on street railway companies the right to propel their cars by electricity.

A telephone company sought to recover from the railway company the sum of $\$ 27,672.07$ for the expense of converting the system from the earth circuit to the McCluer Device, it being admitted that the necessity for the change was occasioned by the railway company.

The decision settled the propositions:

I. That the telephone company was bound to make the change sooner or later, because of the growing use of electricity, irrespective of the railway companies.

2. The use of the highway for travel is superior to any other use.

3. The Sprague system is a lawful and proper one. 
4. The use of the earth for a return circuit is not the exclusive property of any company.

5. A street railway company cannot be compelled to use a double trolley system.

6. The telephone company cannot recover the expense of changing its system from an earth circuit system to the $\mathrm{McCluer}$ or common return system. ${ }^{60}$

38. Private persons cannot restrain exercise of electric franchises.

And that seems to be view that must prevail in the United States. For citizens as such have no power to compel by mandamus the removal of electric railway poles that have been erected under authority granted by a borough. ${ }^{61}$ And a fortiori, the abutting owners are equally powerless to abate a statutory nuisance, assuming the maintenance of a street railway to be a nuisance. ${ }^{62}$ Abutting owners cannot enjoin the erection of a single overhead wire trolley system, ${ }^{63}$ nor can a single owner enjoin the erection of poles before his own lot. But this does not mean that he is not to be compensated for any injury that he may have suffered in consequence. ${ }^{64}$ Nor can he prevent the change from horse power to electric power. ${ }^{65}$

(60) Bell Telephone Co. v. Montreal St. Ry. Co., 6 Q. B. 223. (Rapports Judicares de Quebec.)

(61) Commonwealth v. West Chester, 9 Pa. C. C. 542, 1891.

(62) Lockhart v. Craig Street Railway Co., 135 Pa. 419, 1891; 21 Atl. Rep. 26, 1891.

(63) Pelton v. East Cleveland Railroad Company, 3 Am. Elec. Cas. 215, 1889.

(64) Tracy v. Troy \& Lansingburgh R. R. Co., 54 Hun. 550; 3 Am. Elec. Cas. 227, 1889.

(65) Tracy v. Troy \& Lansingburgh R. R. Co., 54 Hun. 550; 3 Am. Elec. Cas. 227, 1889. 


\section{CHAPTER VI.}

PRIORITY OF FRANCHISE AS CONFERRING VESTED RIGHTS.

39. First franchise holder must not be disturbed.

40. Priority in a given territory gives vested rights.

41. Exclusive franchises against public policy.

42. Invading companies may be restrained.

43. But private uses must give way to public ones.

39. First franchise holder must not be disturbed.

Normally, the holder of the earliest franchise in point of time has a vested right to the undisturbed exercise of its franchise. This has been modified occasionally to establish the principle that a public use is superior to all other uses, and hence, that even a prior licensee must yield to a later one which has secured a public contract. This doctrine is open to criticism. In the case under consideration, an electric light company had erected poles and wires and was operating its lines in the city of Terre Haute, when a second company which had been awarded a contract for lighting the city streets, erected its poles and wires in such a manner as to interfere seriously with the operation of its lines by the first company. The court compelled the first company to make whatever changes were necessary to avoid conflict, upon the theory that the public contract was awarded with the tacit condition that the successful bidder must have the undisputed right to the city streets for its poles and wires. ${ }^{66}$ There is more in this decision than appears. For, the proposition settled by the court, if sound, means that no rights vest in the first licensee which the municipality is bound to re-

(66) Terre Haute Electric Light \& Power Co. v. Citizen's Electric Light \& Power Co., 1 Am. Elec. Cas. 193, 1895. 
spect, it has only to grant a public contract to a second licensee, to divest the rights previously granted to the first licensee. This is not in accord with reason, nor with the weight of authority. The first licensee having in good faith established its plant by virtue of the license from the municipality, has acquired a contractual right to operate its lines undisturbed by municipal or any other authority. If, therefore, the city creates new conditions by awarding a public contract to a second licensee, the expense of making any changes in existing systems of lighting for example, should be borne by the newcomer.

The courts are not in harmony as to the adjustment to be reached, where the invading railway company compels the telephone company to protect itself by adopting a complete metallic circuit. The courts of Ohio and Tennessee usually permit the telephone company to recover the additional expense to which it is put by the railway company, but they deny an injunction to restrain the operation of the railway. ${ }^{67}$

Again, in Canada, interference was restrained in the case of Bell Telephone Co. v. Belleville Electric Light Co., but the defendant in that case was an electric light company and not a railway company. ${ }^{68}$

In the absence of statute, the first party erecting a telephone line, has superior rights, and the second company in the field must not interfere with them. ${ }^{69}$

(67) Central Union Telephone Co. v. Sprague Electric Railway, etc. Co. and the Akron Street Railroad Co., $2 \mathrm{Am}$. Elec. Cas. 307, 1889; East Tennessee Telephone Co. v. The Chattanooga Electric Street Ry. Co., 2 Am. Elec. Cas. 323, 1889.

(68) Bell Telephone Co. v. Belleville Electric Light Co., 12 Ontario, 571, 1886.

(69) Northwestern Telephone Co. v. Twin City Telephone Co., 89 Minn. 495, 1903; 95 N. W. 460. 


\section{Priority in a given territory gives vested rights.}

The principle established is, that electric companies exercising similar franchises have equal rights, but priority in time carries superiority of right. Both franchises, in a court of equity, will be so controlled as to admit of the operation of both, but if conflict be unavoidable the company last in the field must give way, and the fact that the second company has secured a public contract does not alter the situation. ${ }^{70}$

Should interference be unavoidable, the later occupant must give way to the former. ${ }^{71}$ And the first licensee may restrain interference whether due to induction or to direct contact of wires. ${ }^{72}$ This is not because of the exclusive right of the first company, but because of its prior right.

The general principle upon which the decision in this case rests is - that a municipality having the power to do so, having granted to an electric light company the right to erect poles and string wires along its streets for the purpose of electric lighting, the company by proceeding to expend money upon the faith of such a license acquires

(70) Edison Electric Light \& Power Company v. Merchants' \& Manufacturers' Electric Light, Heat \& Power Co., $200 \mathrm{~Pa}$. 209, 1901; 49 A. 766; Consolidated Electric Light Co. v. People's Electric Light \& Gas Co., 94 Ala. 372, 1892; 10 So. 440, 1892; Monongahela L. \& R. Co. v. Rose Hill Elec. Lt. Co., 30 P. L. J. (Pa.) 301; 9 Am. Elec. Cas. 838, 1906; Montgomery Lt. \& W. P. Co. v. Citizens' L. H. \& P. Co., 147 Ala. 359; 40 So. 981; 9 Am. Elec. Cas. 776, 1906.

(71) Edison Electric Light \& Power Co. v. Merchants' \& Manufacturers' Electric Light, Heat \& Power Co., 200 Pa. 209, 1901; 49 A. 766.

(72) Rutland Electric Light Co. v. Marble City Electric Light Co., 65 Vt. 377, 1893; 26 Atlantic 635; 27 L. R. A. 821. 
a vested right to use the streets for that purpose which the municipality cannot impair. ${ }^{73}$

A second company, therefore, cannot under a subsequent grant of the municipality erect and maintain its poles and wires in such a manner as to interfere with the first. Such interference will be enjoined. The principle that a telephone company by erecting its poles and wires under license from a municipality, acquires a vested right which neither the municipality nor subsequent licensees could interfere with, seems generally conceded. ${ }^{74}$

The effect of these decisions is not that any company by obtaining a franchise obtains an exclusive privilege. The intent is that the municipality having granted the franchise binds itself also to protect the holder of the franchise against unlawful interference at least. It has been held that this privilege or franchise is not such that the first company may prevent a subsequent licensee from paralleling or overbuilding its lines, whether parallel or upon, in any such a manner as will not prevent the proper operation of the old company's lines. ${ }^{75}$ Conversely, the first company in the field should be protected if there is actual interference, and this is the law. ${ }^{76}$

\section{Exclusive franchises against public policy.}

The policy of the law works generally against exclusive rights or exclusive franchises. But priority, where con-

(73) Rutland v. Marble City Electric Light Co., 65 Vt. 377 ; 26 Atl. Rep. 635; 27 L. R. A. 821; 4 Am. Elec. Cas. 256, 1893.

(74) Hudson v. Jersey City, 49 N. J. L. 303; Nebraska Telephone Co. v. York Gas \& Electric Co., 27 Neb. 284; 43 N. W. 126; 3 Am. Elec. Cas. 364, 1889.

(75) Chicago Telephone Co. v. North Western Telephone Co., 199 Ills. 324, 1902.

(76) Chicago Telephone Co. v. North Western Telephone Co., 199 Ills. 324, 1902. 
flict is inevitable may have that effect. Railways or telephone companies acquire no exclusive vested right, but if the holder of a subsequent franchise cannot exercise it, without interfering with the first comer, he cannot exercise it at all. ${ }^{77}$ Conversely, if the second telephone company, or the second railway company can exercise its franchise without an unlawful interference with the first company, the first company cannot restrain its operation. ${ }^{78}$

And new companies may parallel and overbuild the old companies so long as no interference takes place, it being settled that a municipality has no power to grant exclusive use of its streets to one company alone, for telephone purposes. $^{\mathbf{7 9}}$

Therefore, if the franchises have equal merit, a corporation occupying a portion of the streets with its equipment under an ordinance, has a right of occupancy which is a property right, that will be as much protected from unlawful invasion as any other property. ${ }^{80}$ The court in this case adopted the reasoning employed in the case of Louisville Home Telephone Company v. Cumberland Telegraph and Telephone Company. ${ }^{81}$

"In the recent case of Louisville Home Telephone Company v. Cumberland Telegraph and Telephone Com-

(77) Pennsylvania Co. $\dot{v}$. City of Chicago, 181 Ills. 289, (1899) ; 54 N. E. 825.

(78) American Telephone \& Telegraph Co. v. Morgan County Telephone Co., 138 Ala. 597; 36 So. 178, 1903.

(79) Chicago Telephone Co. v. North Western Telephone Co., 199 Ills. 324; 65 N. E. 329, 1902; affirming 100 Ills. App. 57.

(80) Chicago v. Baer, 41 Ills. 306 (1866); Rich v. Chicago, 152 Ills. 18 ; 38 N. E. 255, 1894 (Lake Street Elec.) Railway Co. v. Chicago, 183 Ills. 75 (1899) ; 55 N. E. 721.

(81) Louisville Home Telephone Company v. Cumberland Telegraph and Telephone Company, 111 Fed. Rep. 663, 1901. 
pany, ${ }^{82}$ where a telephone company constructed its line in the streets of a city under a franchise granted therefor, which expressly reserved the right to the city to grant similar rights to other companies, and a franchise was granted afterward to a second company, which was required to construct its line under the direction of the board of public works, and such board required its line on certain streets to be placed on the same side and over the same space occupied by the first company, it was said by the court: "The Circuit Court appears to have accepted as correct the contention of the complainant that, by its prior occupation of the space which it occupied by erecting its poles, cross-arms, and wires over a width of eight feet and at the height of twenty-five feet, it acquired an exclusive right to occupy that width of space from the ground upward without limitation and this without any intrusion by another party. In this the court misconceived the nature and extent of the rights of the complainant. It may properly be conceded that its prior occupation of space, under the franchise granted by the statute and ordinance, would entitle it to continued enjoyment thereof, so long as it continued to perform its obligations, without substantial impairment. But its right is not absolutely exclusive. It is subject to such incidents as result from the exercise of the rights of other parties, who have acquired a valid franchise of similar character. It is implied in such grants, as were here made to the first company, that the grant is subject to such limitations, as will enable another company to enjoy a like franchise, and no property right is invaded by the adoption of such measures by the second company, as will enable it to exercise its privilege, provided there is no un-

(82) Louisville Home Telephone Co. v. Cumberland Telegraph and Telephone Company, 111 Fed. Rep. 663, 1901. 
reasonable and unnecessary invasion of the operations of the first occupant. For the property right of the first is not to a monopoly. It is bound to exercise its privilege in such a way as to give room to another coming in under the power reserved. In the present case, the common council of the city expressly reserved the authority to grant to others, if it should deem it for the public interest, the same privileges in its streets as it granted to the complainant. It is not intended, of course, to say that the first occupant may be despoiled, or the substance of its right appropriated. But this does not happen from merely giving place to a rival company, whose presence was expressly stipulated for by the contract, nor, probably, if the presence of the new party was the result of the exercise of a power reserved by implication in such a grant of privileges." 83

"In Illinois Central Railroad Co. v. City of Chicago, ${ }^{84}$ where a court of equity was asked to grant an injunction against interference with the operation of a railway at a street crossing, this court said (p. 603) : "It is well understood that the track or right of way cannot, in the nature of things, be restored to the same state of usefulness with the street thereon, as before. It is to be restored, so as not to impair its usefulness more than is necessary in view of its use for the purposes of a street, subject to the use by the railroad company; it is not to be rendered less useful, except in so far as diminished safety

(83) Cumberland Telegraph and Telephone Co. v. United Electric Railway Co., 42 Fed. Rep. 273, (1890) ; 12 L. R. A. 544; Telephone Co. v. Railway Co., 3 Am. Elec. Cas. 350, (1889); Western Union Telegraph Co. v. G. \& S. Light Co., 46 Mo. App. 120, (1891) ; Illinois Central Railroad Co. v. City of Chicago, 141 Ills. 586, (1892) ; 30 N. E. 1036.

(84) Illinois Central Railroad Co. v. City of Chicago, 141 Ills. 586; 30 N. E. 1036. 
and convenience are inseparable from its use by the public as a street crossing. It is not expected that the crossing can be restored so as to obviate all danger, or delay, or inconvenience. It is only necessary that there should be no unreasonable impairment of the usefulness of the railroad right of way."

"One of the interferences with appellant's system of telephone, which is charged against appellee, is that, in many of the streets of the city, appellee has erected its telephone poles and strung its telephone wires upon the same side of the street where the telephone poles and wires of appellant are set and strung, and that appellee has been guilty of overbuilding the poles and wires and telephone system of appellant; that is to say, that it has strung its wires above the telephone wires of appellant, instead of stringing them below the same. In other words, appellee is charged by appellant with "overbuilding" and "paralleling," as the terms are used by the expert witnesses.

"If the city has no right to grant the exclusive use of the street to one telephone company, and has the right to grant the use thereof to two or more telephone companies, then the right of a later telephone company, coming into the street, to place its telephone lines upon the same side of the street with the telephone company coming earlier therein, necessarily results as a matter of course. There are only two sides to each street, and if there are more than two telephone companies, two of them must necessarily be on the same side of the street. If one telephone company has no right to the exclusive use of the street, it has no right to the exclusive use of one side of the street. In the case at bar, the evidence shows that, on many of the principal residence streets in the city, appellant has its poles and wires set and strung upon both sides of the street. Necessarily, therefore, in such cases 
the appellee was obliged to be, for a part of the route at any rate, upon the same side of the street with appellant." In the case already referred to, of Louisville Home Telephone Company v. Cumberland Telegraph and Telephone Company, ${ }^{\text {s5 }}$ supra, it appeared that the second company placed its line of poles and wires on the same side of the street occupied by the first company, and this was there held to be no substantial interference with the rights of the first company. The right of the appellee to be upon the same side of the street with the appellant is substantially conceded by the appellant in its bill, because it therein avers that "it was and is the duty of said Northwestern Telephone Company to so construct its lines, as not to unnecessarily interfere with the system and lines of your orator; that it was and is the duty of said defendant company in the construction of its lines, in cases where it is absolutely necessary to cross or parallel the lines of your orator, to underbuild the lines of your orator." This allegation is in effect an admission that, where it is absolutely necessary, appellee can parallel appellant's lines of wires, that is, can be upon the same side of the street with appellant. ${ }^{86}$

The question of conflicting uses, narrows itself down at times, to problems of the utmost nicety. Suppose that the problem is whether or not the placing of a line of electricity carrying 20,000 volts within three feet of a telephone line carrying 100 volts, is negligence per se. This was held in a California case to be no evidence whatever of negligence in the construction of the line of an electric power company. While the actual case involved liability

(85) Louisville Home Telephone Co. v. Cumberland Telegraph and Telephone Company, 49 U. S. Cir. Ct. of App. 524.

(86) Chicago Telephone Co. v. North Western Telephone Co., 199 Ills. 324, 1902; affirming 100 Ills. App. 57; 65 N. E. 329. 
for damages for the destruction of property by fire, the principle involved is of extreme importance. Let us examine the facts. On the 7 th of September, r902, a telephone terminus was maintained in the town of Orland, California. The Northern California Power Company erected a power line between Orland and Germantown, in the State of California, and the lines of the power company were placed within three feet of the lines of the telephone company. The result which may be ascribed to placing the two lines in such close proximity to each other, was that the wind blew the telephone lines against the power line, with the result that the telephone terminus was destroyed by fire. It was admitted by the court in reaching a decision that the fire was no doubt caused by contact between the telephone wire and the high power wire of the power company. It was also admitted that the wires came into contact because of a storm. It must be observed in passing on the merits of this case that in all cases where two wires come into contact, belonging to different companies, and a third person is hurt, the two companies are joint tort-feasors. In this particular case, the plaintiff was the owner of the terminus of a private telephone line. The question as stated by the court was, "Is it negligence for a power company to place its posts within three feet of a telephone company's line?" This is obviously an unfair statement of the problem, because the real question is whether or not it is negligence to place posts within three feet of a telephone company's line when the difference of potential between the two lines is at least 19,000 volts. The court held as a matter of fact, that it was not negligence for the defendant to put its power line three feet from the telephone lines. The court suggested that it was incumbent upon the plaintiff to allege and prove that the defendant power company 
when it built its power line, did not build it in a careful, workmanlike manner, and in a manner to make it safe as regards the persons and property of the public; that it did not use due diligence to make it safe when its position and proximity to the telephone line was considered. The court said further: "Does the mere undisputed fact that the defendant constructed and maintained its line which was of 20,000 volt power, a much higher voltage than that of the telephone line, within a distance of three feet from the telephone line, warrant the presumption of negligence on the part of the defendant? No such presumption of law arises upon the proof of that fact."

The reasoning of the court in this case is one of the most remarkable instances of misapprehension of legal principles upon record. If the test usually given of negligence be applied, whether or not an ordinary commonsense man would have acted so under the circumstances, then this case falls far below the legal standard universally established in the United States as well as in California. There is not one whit less danger in a rapidly moving buzz saw than there is in a wire carrying 20,000 volts of electricity placed within three feet of other wires of much less voltage. And yet, the same court would scarcely hesitate an instant to say that an owner who left a moving and exposed buzz saw on the street where passersby might come into contact with it by the merest accident, was guilty not merely of negligence, but of wanton, culpable negligence. How then it can be imagined that the placing of a wire carrying 20,000 volts of electricity within three feet of another wire, which the rain or wind, or the snow, or the thunder and lightning, or any other cause likely to happen at any moment, might throw upon the heavily charged wire, is not negligence, it is difficult to comprehend. At all events, part of the decision may be 
due to the fact that the plaintiff did not offer adequate proof of the negligence of the defendant company. But that the case of Brown v. The Northern California Power Company should ever become a precedent for the general proposition decided would be a matter for much regret. ${ }^{87}$

\section{Invading companies may be restrained.}

In cases of conflict of this nature, it may be stated as a general principle, that an invading electric company may be restrained by the holder of the first franchise from placing its wires within a "harm-producing zone" of the first company's wires. Thus, in the case of Paris Electric Light and Railway Company v. Southwestern Telegraph and Telephone Company, ${ }^{88}$ the electric light company was restrained from maintaining its wires nearer than four feet from those of the petitioner, a telephone company. In the case of Western Union Telegraph Company v. Los Angeles Electric Company, ${ }^{89}$ the electric light company was restrained from operating its wires so as to cause injury to the telephone company by induction.

It is rarely that a telephone company seeks to place its wires close to those of an electric light company, but, it having been shown that the electric light company, the plaintiff, could not be injured by having the telephone wires placed near its own wires, the court refused to restrain the erection of the telephone wires. ${ }^{90}$

And the principle is now universally conceded that not-

(87) Brown v. Northern California Power Company, 114 Pacific, p. 74, 1910.

(88) Paris Electric Light \& Railway Co. v. Southwestern Telegraph \& Telephone Company, 5 Am. Elec. Cas. 262, 1894.

(89) Western Union Telegraph Company v. Los Angeles Electric Company, 6 Am. Elec. Cas. 202, 1896.

(90) Nebraska Telephone Co. v. York Gas \& Electric Light Co., 43 N. W. 126, 1889. 
withstanding a grant of an exclusive franchise to occupy the city streets to one electric company, a later company cannot be prevented from entering the same territory where there is no conflict in the exercise of the two franchises, other than mere business competition. ${ }^{91}$

This distinction may be taken as established:- that priority of time never means a vested right to a monopoly of the business in a given territory. If the franchises can be exercised simultaneously both have a right to operate.

\section{But private uses must give way to public ones.}

If the conflict in the use of electricity be between a holder of a franchise and one who has no franchise, the public use being higher than the private use, must be preferred. And the fact that the private user of electricity is first in the field is of no weight.

An electric light company holding a franchise to operate in the city of Pittsburg, was sued by the owner of a small electric light plant to enjoin the electric company from cutting the wire of the plaintiffs, which was stretched across a street on which the electric light company operated. The electric light company cut the wire frequently, on the ground that it endangered the public and its consumers because of the possibility of contact of the two systems.

The plaintiff's wires were lawfully placed. They had the consent of the owners upon whose houses the wires were attached, and the wire did not interfere with the use of the highway.

It was decided that the maintenance of the wire was

(91) Grand Rapids Electric Light \& Power Co. v. Grand Rapids E. E. L. \& F. G. Co., 33 Fed. Rep. 659, 1888. 
not as such a nuisance, but might be if it interfered with a public user.

"To constitute an interference with the public user of the street by the light company, it is not necessary that the wire complained of should be in contact with those of the light company, or physically obstruct the wires or poles of that company. We are of opinion that if its existence endangers wires of the light company to any appreciable extent, it must be deemed to be a nuisance.

"The light company being specially injured by the maintenance of the wire of the complainants, being the only party who is injured thereby, has standing to maintain the bill for its removal."

The maintenance of the private wire was enjoined.

The Supreme Court affirming this decree said "The wire described in the findings of fact is one that passes across the street, near the plaintiff's wires, the maintenance of which interferes in some measure with the use of the street by the plaintiff, endangers the lives of its customers, imperils its property, and entails an additional expense for inspection." 92

(92) Wettengel v. Allegheny County Light Co., 223 Pa. 79, 1909. 


\section{CHAPTER VII.}

PRINCIPLES BEARING ON CONFLICTING USES OF ELECTRICITY.

44. Consequences of doctrine that railway is a dominant use of the highway.

45. Facts for the jury.

46. Statutory authority answers elaim that franchise is a nuisance.

47. Does the electric light facilitate travel?

48. The doctrine of Rylands v. Fletcher.

49. Contrast of English and American principles.

44. Consequences of doctrine that railway is a dominant use of the highway.

It will be found generally that the corollaries of the doctrines that the street railways further travel, and constitute a dominant use of the highway in cities are followed in all of their logical consequences. Assume the principle that the railway is a dominant use; that it adds no new burden to the streets; from this we reason that the erection of trolley poles does not add a new burden to the streets, and does not constitute a nuisance. Suppose, then, that an abutting owner seeks to enjoin the erection of trolley poles on the ground that the telephone service in his house would be rendered useless by induction from the trolley wire. Clearly the injunction cannot be granted. For,

If a nuisance, it is a public nuisance affecting the community or a part of it generally, but

A public nuisance can be redressed by a private citizen only by showing injury special to himself. ${ }^{93}$

(93) Morris \& Essex Ry. Co. v. Newark Passenger Ry. Co., 51 N. J. Equity 379; 29 Atlantic 184, 1893. 
And this injury affects the entire telephone-using public.

Or, to cling to the text, the railway franchise is superior, it is not a nuisance, and the telephone compaily cannot accomplish indirectly through a private citizen, what it is unable to enforce as the holder of a franchise. ${ }^{94}$

\section{Facts for the jury.}

Narrowing the problems involved still further it seems that the jury and not the court must determine whether or not the fact that the street railway company failed to erect guard wires over its trolley wires to prevent telephone and other wires from falling across it constitutes negligence. ${ }^{95}$

Whenever the use of a public street by the licensee is antagonistic to its use as a public highway, such private use must give way to the public use. But this is not so, as to incidental damages to abutting owners for injury due to the erection of poles. ${ }^{96}$

\section{Statutory authority answers claim that franchise is a nuisance.}

In England we have seen, the recognition of a franchise by the national government is of itself an answer to any claims that the exercise of the franchise is a nuisance. In the United States, the franchise does not gain so much potency by reason of government recognition as in England. The act of July 24, I866, Rev. Stats. U. S., Secs. 5263 to 5268 , is entitled "An act to aid in the con-

(94) Simmons v. City of Toledo, 8 Ohio C. C. R. 535.

(95) Block v. Milwaukee Street Railway Company, 89 Wis. 371, 1895; 27 L. R. A. 365; 61 N. W. 1101.

(96) Julia Bldg. Assn. v. Bell Telephone Co., 13 Mo. App. $477,1883$. 
struction of telegraph lines, and to secure to the government the use of the same for postal, military and other purposes." The Richmond and Southern Bell Telephone and Telegraph Company contended that it might use the streets of Richmond irrespective of the city's consent or even against it. The Supreme Court of the United States construed the act however, to subject companies formed under it to reasonable police regulations of cities and States. It was also intimated that the act quoted had no application to telephone companies whose business is that of electrically transmitting articulate speech, between different points. ${ }^{97}$

\section{Does the electric light facilitate travel?}

A question has arisen in Rhode Island that may modify the position, both of street railways and telegraph and telephone companies. It was suggested there, that an electric light company may be considered the holder of a dominant franchise, its purpose being to light the streets and thus facilitate public travel. Should this view prevail, the comfortable position of street railway companies might be disturbed, and the uncomfortable position of the telephone and telegraph companies might be rendered still more uncomfortable. ${ }^{98}$

The question of how far an electric light pole constitutes a servitude upon the highway, was discussed in that case as follows: "We are not inclined to say, however, that they do not encumber because they are placed as they are, but only that it does not follow that they encumber because they are so placed.

(97) Richmond v. Southern Bell Telephone \& Telegraph Co., 174 U. S. 761, 1899.

(98) Taggart v. Newport Street Railway Company, 16 R. I. 668, 1890; 19 Atlantic 326. 
Take, for instance, a lamp post or an electric light pole. It is slightly in the way, and, if it served no useful purpose in regard to the street might justly be deemed to encumber it. But it supports a lamp, or an electric light, which illuminates the street at night, and so improves the street for its proper uses. It is not, therefore, an encumbrance in any proper sense of the word. ${ }^{99}$

This decision must not be considered as standing alone, for it had been held prior to that time, that a telegraph pole erected by a railroad company within its location for the purposes of its railroad, to increase the safety and efficiency thereof, does not constitute an additional servitude, but is only a legitimate development of the easement originally acquired. ${ }^{1}$

\section{The doctrine of Rylands $\nabla$. Fletcher.}

Let us now see how far the principles of the case of Rylands v. Fletcher, ${ }^{2}$ the leading English case on the subject of liability for injuries wrought by dangerous agents which one keeps upon his land and permits to escape, apply. The wrong done by the defendant, a mill-owner, consisted in maintaining on his land a reservoir of water, admittedly a proper use to make of land. The water escaped, without negligence on the part of the mill-owner, and flooded the mines of the complainant, the lessee of the mines on the adjoining property. Two principles were necessarily involved in the decision of the cause:

I. A landowner may put his land to any of its ordinary uses without incurring liability for any mischief inci-

(99) Taggart v. Newport Street Railway Co., 16 R. I. 668, 1890; (19 Atlantic 326.)

(1) Western Union Telegraph Co. v. Rich, 19 Kans. 517, (1878.)

(2) Rylands v. Fleteher, L. R. 3 H. L. C. 330, 1868. 
dentally wrought, provided he is guilty of no malice nor negligence.

2. A landowner who brings upon his land anything which would not naturally come upon it, which is dangerous in itself, and productive of harm if uncontrolled, is liable for any harm done, whether negligently or not.

The doctrine of this case is really one of the landmarks of legal development. For it suggested a test of liability that is really fundamental. Without wandering too fár afield, let us apply the analysis of that case to problems of the sort under discussion. When a corporation, or an individual stores electricity, (which all of the cases agree, is an agent so manifestly dangerous, that one who uses it is almost an insurer that no harm will result), upon his premises, it or he does it for his own profit or pleasure. Suppose then, for any reason, that it escapes beyond control, what answer is it to his innocent neighbor, whose property it destroys, whether he was or was not guilty of neglect?

The principles of Rylands v. Fletcher apply in England in all cases where a dangerous agent has been permitted to escape. A vicious dog, gunpowder, or any similarly dangerous object are instances of things that by their very nature compel their owners or keepers to assume a relation of insurance toward the rest of the world. Now, it happens that at first the American courts repudiated the doctrines of Rylands v. Fletcher, and adopted the general principle that wherever harm is caused by the use of an object, whether dangerous per se, or not, he is liable for the consequences only where he had been negligent in failing to control his agent. ${ }^{3}$

(3) See the Rule in Rylands v. Fletcher, by Prof. Francis H. Bohlen, University of Pennsylvania Law Review and American Law Register, Vol. 59. 
But certainly in cases where electricity escapes and produces injury by conduction, by electrolysis or otherwise, it seems that the rule of Rylands v. Fletcher will be applied in all its strictness. The case of Peoria Waterworks Company v. Peoria Railway Company, ${ }^{4}$ discussed hereinafter, seems to be typical of the general legal view toward injuries of this kind.

\section{Contrast of English and American principles.}

The decision of cases of conflicting uses of electricity in England will generally differ from the rules discussed above, by reason of (I) The fact that the doctrine of Rylands v. Fletcher is not generally accepted in America, even if applicable to such a case. (2) The questions of relative value of franchises and of the dominant use of the highway have not been considered except in the Canadian cases.

The English court will therefore apply the doctrines of Rylands v. Fletcher, but will say perhaps, that those doctrines will not protect one who uses an apparatus of such delicate construction that a powerful electric current will injure it. The reasoning is not altogether clear. If the principles of Rylands v. Fletcher were applicable at all, they should protect an owner of a telephone as well as the owner of a mine. If the telephone must be remodeled, the expense of the change should, on this principle, be borne by the railway company. And such in fact was the doctrine of the earlier cases. But inasmuch as under the decisions, it is held that the performance of an act in pursuance of a statutory authority protects the doer of it from liability for the maintenance of a nuisance, the result reached is almost the same as that reached in the United

(4) Peoria Waterworks Company v. Peoria Railway Company, 181 Fed. Rep. 990, 1004 (1910). 
States. It is interesting to contrast the reasoning used in the two classes of cases, by which the same conclusion is reached. The English doctrine is :

(a) The nuisance if authorized by statute is not enjoinable.

(I) Unless negligence appear in the exercise of the franchise.

(b) Injury to a delicate trade apparatus, such as a telephone unnecessarily so constructed, is not actionable.

The American doctrine is :

I. The principles of Rylands v. Fletcher do not apply.

2. The escape of electricity from the rails is not a nuisance per se, and is damnum absque injuria, unless negligence is shown in its use.

3. The railway company has a dominant right to the use of the street and whatever change is necessary, must be made by the telephone company.

It will be seen that the legal effect of $x$ and (a) of the English doctrine is precisely the same as that of 2 and (a) of the American doctrine, and that (b) of the English doctrine operates in effect as does 3 of the American principles. For to say one is liable for the escape of a dangerous agent unless its use be authorized by statute, is the same as saying that a corporation holding the franchise to use the agent cannot be held for its escape in ordinary use; and that the rule as to dangerous agents does not apply. (b) of the English doctrine corresponds to 3 of the American principles, for the effect of holding that the use of a delicate apparatus is not entitled to protection is equivalent to holding that of the railway franchise dominant and placing the burden of change on the telephone company. Analysis will disclose that the refusal of relief to the telephone company is maintainable, if at all, only on the American theory. 
There is no basis for applying the doctrine of Rylands v. Fletcher; a person authorized to put his property or apparatus in a public street not being a landowner in such a sense as to make the holder of other franchises, or the public generally, an insurer of his property-he is entitled only to protection against unlawful invasion. But, having applied the principle to such a case, the exception of delicate trade instruments, unnecessarily so constructed is an anomaly. Under this reasoning, the mine owner should have kept the entrance to his mine galleries water tight, and there would have been no doctrine of Rylands v. Fletcher. 


\section{CHAPTER VIII.}

ADJUSTMENT ON EQUITABLE PRINCIPLES. SUMMARY.

50. The equitable treatment of conflicting uses.

51. Relief where a railway unnecessarily interferes.

52. What kind of relief may be sought.

53. The street railway is a burden on country highways.

54. The discharge of electricity into the earth as a nuisance.

55. Summary of principles.

50. The equitable treatment of conflicting uses.

In the case of Cumberland Telegraph and Telephone Company v. The United Electric Railway Company, ${ }^{5}$ the court sought an equitable adjustment of the problem presented where the territory of an existing telephone company is invaded by a street railway company.

The telephone company had established its lines and conducted a satisfactory business, using the earth as a return circuit, until the advent of the street railway. The usual conflict of the electric currents followed. The telephone company was finally obliged to protect its service by the installation of the McCluer device. In the case under discussion it was found as a fact that the railway company which was operated as a single trolley system, also made use of the earth as a return circuit. The injuries complained of were due to induction as well as conduction.

The injury due to induction, it was found, could be avoided by eliminating the parallelism of the two systems, and this could only be done at a reasonable expense, by

(5) Cumberland Telegraph and Telephone Co. v. The United Electric Railway Company, 93 Tenn. 492, 1894; 29 S. W. 104; 27 L. R. A. 236, 1894. 
the telephone company. The telephone company did this at an expense of $\$ 856.30$.

The injury due to conduction was eliminated by the telephone company by installation of the McCluer device, at an expense of $\$ 3,660.58$.

The telephone company sued to recover the damages thus sustained and the court allowed a recovery.

It is believed that this decision represents the trend of the sounder legal thought upon the subject.

The court said: "There is no necessary conflict between the rights and franchises of these companies. There is not any unavoidable repugnancy between the statutes upon which they respectively rely. The electric railway plant can be operated, under proper limitations as to distance and apparatus, without causing injury to telephone plants by conduction. This fulfills the defendant's grant without trenching upon the pre-existing rights of plaintiff. If defendant seeks to have a more beneficial use of its plant by an invasion or use of plaintiff's property, it is just that compensation should be made."

The question of how far the contention of either party to a controversy of this kind that it might exclude the other from discharging electricity into the earth, that is to say, use the earth as a return circuit, amounts to a claim of a monopoly in the use of the earth as a return circuit, was considered, and in the writer's opinion, conclusively answered. It was said: "It is insisted by defendant that plaintiff cannot recover the damages caused by conduction except upon the theory that it has the right of the exclusive use of the whole earth for electric purposes. A monopoly of the earth's use for any purposes, or by any person, is of course, inadmissible. The plaintiff, however, repudiates this ambitious and extravagant claim, and insists that its demand is the more modest and 
reasonable one for exclusive use of electricity upon its own premises, in an authorized and non-hurtful manner, without injurious disturbance from non-hurtful electric conditions caused by the defendant's acts."

The court, having summarized the facts to the effect that both parties were using the earth as a return circuit, and remarking that in the operation of the defendant's plants, large and turbulent artificial currents of the electrical fluid were generated and poured into the streets beyond defendant's control, found as a fact that the abnormal currents were to be found doing injury upon private property of the plaintiff and its subscribers. It was found that the injury by conduction could be obviated at an expense which entailed no great hardships upon either party.

The conclusion of the court was that the plaintiff had the right to the protection of the courts in the adjustment of its property, franchises, easements and the ability to use property, which though intangible, have value, and are, equally with tangible property, entitled to the recognition and protection of the courts. "If plaintiff's claim, that contemplates no more than a lawful and non-hurtful use of its own property, shall be characterized as a demand for the monopoly of the whole earth, what shall be said of defendant's larger demand for a hurtful use not only of the streets, but of private property for half a mile on either side? The plaintiff's request is 'Let me alone in that use or application of electricity upon my own premises, that causes no harm or disturbance to any one anywhere.' The defendant's command is: 'Get out of my way!' to all feebler electrical enterprises that may have the misfortune to come within the range of its power."

"The plaintiff proposes an adjustment of conflicting claims with defendant by the rule embodied in the enlightened maxim, sec utere, etc., while defendant insists 
upon the application of that ruder maxim, 'Might makes right.' If defendant could succeed in its contention, there can be little doubt that the unjust rule thus established would some day 'return to plague the inventor.' What protection has this defendant in the enjoyment of its vast properties, if it can be deprived of the power to operate them by some younger, but more robust, child of invention that shall hereafter obtain mastery in the electric world? Is not the non-injurious use of electricity the only safe and just basis for the adjustment of the conflicting claims of electrical inventions and enterprises? What different basis than this can be arbitrarily established? Where shall the line be drawn between those electrical enterprises that must take care of the artificial currents of electricity generated by them, and those that shall not be required to do so?" (Writer's italics.)

"To concede defendant's claim is to give to it a hurtful use of plaintiff's property, and at the same time to deny plaintiff the harmless use of its own. The argument that assumes that plaintiff is claiming the whole earth as a return circuit, and therefore appropriating a common right to its exclusive use, because 'plaintiff's portion of the earth cannot be isolated and separated electrically from the balance of the earth,' is one which, if pressed to its logical results, would work a revolution in the law as to the use of the earth, the water, and the air. How, if this argument be sound, can any one insist that the air and water, that, by the operation of natural law, visit his premises and support life, shall not be rendered noisome and impure by the injurious acts of his neighbor? It is impossible that his portion of the air or water can, in advance, be 'isolated and separated from the balance.' Is not the right to the use of air and water as 'common' as that to use electricity, If the right to the non-hurtful use 
upon one's own premises, without injurious disturbance from others, of air or water or electricity, is made to depend upon his ability to isolate and separate, in advance, his portion of these elements from the 'balance,' that right resolves itself into an 'airy nothing.'

"The suggestion that plaintiff, in using the earth as its 'return circuit,' appropriates and uses electrically the properties intervening between its 'exchange' and its subscribers' stations in any other than a lawful manner, is, as we think, based upon a misconception.

"The plaintiff's use of electricity causes no disturbance electrically upon these intervening properties or elsewhere, and affords no inducing cause, there or elsewhere, for the invasion of its property by defendant's artificial currents.

"The plaintiff uses the intervening or other outside properties for electrical purposes in no other sense than it uses abutting lands as a part of the framework of the earth to support its own; or uses the channel of the stream upon adjoining lands that conveys the water, by natural flow, to its own; or uses the law of gravitation that causes the water to flow toward its land instead of in the opposite direction. The plaintiff does not assert the right to an injurious use of electricity, even upon its own premises.

"The doctrine that reason sanctions and justice approves, as it appears to us, is that the lawful, harmless, and accustomed use upon one's land, alike of water, air or electricity, cannot be lawfully obstructed or impaired by the injurious act of another, attended with such disturbance of natural and existing conditions, and consequent loss. as that caused by conduction in this case, especially when the party performing the injurious act, had the power to obviate and remedy the injury or loss, without greater 
sacrifice, comparatively, than is required of defendant in this case to remedy conduction.

"It is not material that the injurious act is done upon the premises of one other than the injured party-as, if the channel of a stream is cut upon adjoining lands, and the water diverted, or the waters are there arrested in their regular flow and then turned loose in flooding quantities."

Three elements of injury to the telephone company by the construction and operation of the street railway appeared in this case, viz: I. Of conduction. 2. Of induction. 3. Of conduction resulting in injury to property of the telephone company situated upon its private property. The relief granted to the telephone company was based upon grounds that furnish food for thought and that seem to offer a fair basis for the user of both franchises. The principles involved may be summarized as follows:

r. The operation of a street railway in the street, with any incidental inconvenience or damage to objects in the street, is a legitimate use of the streets within the purpose of their original dedication, but.

a. This principle does not extend to property rights outside the streets.

2. Telephone and other companies may not obstruct the operation of street railways.

3. Both telephone and railway companies must exercise their powers with a careful and prudent regard for the other's rights.

4. If the "ordinary use" of a railway franchise be such as to injure the telephone franchise unnecessarily, the cost of any change necessitated must fall upon the street railway.

5. The railway company is not liable for injuries to 
the lines of the telephone company on the same streets, due to induction, or conduction.

6. The railway company is liable for damages inflicted upon the telephone exchange located upon private property outside of the streets, by conduction.

7. If the telephone company can protect its lines by the adoption of the McCluer device, (a large copper wire, attached at both ends to the out-going (from its exchange) telephone wires), the cheapest effective remedy for injury by conduction, and capable of being applied alone by the telephone company, it is the right and duty of the telephone company to resort to the device, and it may recover the cost of installing it from the railway company.

\section{Relief where a railway unnecessarily interferes.}

This decision proceeds from a point of view, widely divergent from those heretofore considered. It was, in the first place, an action at law, to recover the expense to which the telephone company had been put to render its lines immune from invasion by the electric currents of the railway; it was not a bill in equity to restrain the operation of the railway. In the second place, the inquiry of the court was directed to the question, "Had the railway company unnecessarily constructed its lines so that injury might result?"

This latter query will repay investigation. It will be recalled that in the case of the injury done to the submarine cable, the thought of the court was that although the employer of a dangerous agent was liable for injuries resulting from its use, that did not protect the owner of a delicate instrument unnecessarily so constructed. This is apparently putting the cart before the horse. If anyone is operating his franchise, and does so in such a manner as to injure another, the natural inquiry would seem to 
be, not whether the instruments of the latter were delicate or not, but whether or not the former could avoid the injury. If he could, but the expense of rendering the apparatus of the latter immune were less, he should be made to bear the expense. It seems almost as if many doctrines that impress one as anomalous in our modern legal principles proceed from endeavoring to establish that one who is injured might not have been injured had he built his apparatus differently instead of discovering what would have happened had the assailant exercised his right with more regard for the rights of others. A man builds his house with steel columns and girders. Electrolysis destroys the beams. He is told the injury would not happen to a concrete house. He builds of concrete. Someone sets up a new franchise involving the use of acids which might attack the concrete and the house crumbles again. Still no remedy, for those acids do not attack traprock and so on, ad infinitum.

\section{What kind of relief may be sought.}

The form of action by which redress is sought is important. If the telephone company seek redress, by praying for an injunction, it must generally fail, for the railway franchise is superior and no monopoly can be had in the earth. But if the telephone company sue for the damages inflicted, it has in many jurisdictions in the United States, a right of recovery, upon principles established in the case last discussed.

The telephone company should bring to the attention of the railway company, the injuries which it is unnecessarily inflicting, their origin, and the remedy, whether it be by the use of additional copper on the part of the railway company or that of the telephone company. If the railway company insist that the adjust- 
ment should be made by the telephone company, it is rational to put upon the railway company the cost of the change. This is not true of injuries due to induction, for which redress is based upon different principles, but it seems that this rule should be applied in all cases of injuries due to conduction. For, it is generally conceded that the only reason for which a railway company permits the current to escape into the earth, is the saving of copper. In other words, although there is a simple device by means of which, at a not inordinate expense, the railway franchise could be exercised without prejudice to the rights or property of other franchise holders, the company chooses to save the copper, at the expense of the holders of other franchises. It becomes necessary then for the telephone company for example, to get rid of this troublesome force which the railway company turns loose, which it does, by itself using the copper wire necessary to take hold of the electricity and return it to the dynamos of the trolley system. It is really a very short step from saying that the railway company is inflicting injury unnecessarily to saying that it is guilty of negligence in the exercise of its franchises. And that, under any theory of the use of the highway or the use of the franchise means liability to the extent of the damage inflicted. Besides this, there is a grave question, whether or not the injury due to conduction is a taking of the telephone company's property for which compensation must be made. As to its apparatus located on property elsewhere than in the streets, it is undoubtedly a taking and in some jurisdictions certainly a recovery in damages may be had.

This may become clear upon consideration of cases upon analogous facts. Under ordinary circumstances two corporations exercising similar franchises have super- 
iority of right according to priority of grant and establishment. If interests conflict, an adjustment will, if possible, be made by a court of equity. If the two franchises cannot be exercised together, the one which is later in point of time, must give way. But avoidable injury will be restrained; negligent injury will be restrained; wanton injury will be restrained. If the wires of the one company conflict with those of the other, the court will compel the company guilty of the interference to change the location of its wires, irrespective of cost.

This creates a situation very closely resembling one in which the conflicting franchises are those of the railway and of the telephone company. One franchise is superior to the other, and an adjustment is reached by which the aggressor is compelled to use his franchise in such a way as to cause no loss or destruction to the others. It is impossible to accept the conclusion that unnecessary injury can be inflicted without regard for the rights of the party injured.

\section{The street railway is a burden on country highways.}

While the proposition holds true in general that a street railway may not be considered in a legal sense, a burden upon the highways of a city or borough, or upon highways that may be termed urban, this is not applicable to suburban conditions. From which the principle may be derived that a street railway is not a burden upon city streets, but it is certainly a burden upon country roads. ${ }^{6}$

This decision would not be of so high an interest to the present discussion, had the conclusion reached affected only the right of abutting landowners to question the railway right to construct its line. But the plaintiff

(6) Pennsylvania R. R. Co. v. Montgomery County Passenger Railway, $167 \mathrm{~Pa} .62$; 31 Atlantic 468, 1895. 
in that case was a railroad corporation, and an injunction was granted at its initiative. Apparently, therefore, regarding the question from the standpoint of interfering uses of electricity, any property or franchise holder aggrieved by the operation of a street railway in the country on highways beyond municipal limits, would not be called upon to meet the proposition that the railway had a superior franchise. In other words, the rights of the parties could be decided upon a basis of legal rights and not upon one of relativity of franchises. It must be remarked in this connection that the tendency of modern opinion is against permitting invasion of the rights of others because of statutory authority. The tendency is marked to reconcile clashing rights or franchises as far as possible, and to repress the harmful features of invasion, even where a statute authorizes it. The proposition legally, that the legislature in granting a franchise, must be taken to have contemplated all harm that might result from its operation rests upon a doubtful foundation at best and the New York cases, at all events, seem decidedly opposed to this view of the law. They have, as we have seen above, refused to sanction the discharge of smoke, etc., by elevated railroads without compensation to persons affected, although it might easily be argued that the legislature must have known that an engine could not be operated without making smoke. ${ }^{7}$

54. The discharge of electricity into the earth as a nuisance.

This leads to the consideration whether, if the discharge of smoke into the air, in quantities such as to produce injury be a nuisance and actionable, why is not the discharge of electricity into the earth in such quantities

(7) Hussner v. Brooklyn City R. R., 114 N. Y. 437, 1889; 21 N. E. $1002,1889$. 
as to produce injury actionable for the same reasons. And we shall find when we consider the cases bearing upon the right of recovery for the direct results of the escape of electricity such as electrolysis that the courts have adopted this view. While it is a general legal principle that "no man is answerable in damages for the reasonable exercise of a right when it is accompanied by a cautious regard for the rights of others, when there is no just ground for the charge of negligence or unskilfulness, and when the act is not done maliciously," 8 this principle is subject to many modifications. And one of the principle exceptions is that no one in the exercise of his own rights, however carefully performed, can with immunity, injure another to such an extent that it amounts to a confiscation of his property. ${ }^{9}$

In the case of Cogswell v. The New York, New Haven and Hartford Railroad Company, ${ }^{10}$ it was queried, "whether the legislature can authorize a railroad corporation to maintain an engine house, under circumstances, which if maintained by an individual, would, by the common law, constitute a nuisance to private property without providing compensation. But if this should be conceded, nevertheless, the statutory sanction which will justify an injury by a railroad corporation to private property without making compensation therefor, and without the consent of the owner, must be express or given by clear and unquestionable implication from the powers expressly conferred, so that it can fairly be said that the legislature contemplated the doing of the very act which occasioned

(8) Panton v. Holland, 17 Johns (N. Y.) 99, 1819.

(9) Radeliff v. Mayor, 4 N. Y. 195, 198, (1850).

(10) Cogswell v. The New York, New Haven and Hartford Railroad Company, 163 N. Y. 10, 1886; 8 N. E. 537. 
the injury; it may not be presumed from a general grant of authority."

This leads us at once to the distinction between cases of electrical interference due to induction and to those due to conduction. As to injuries inflicted by a railway or other electrical company upon another electrical company using a lower voltage by induction, this in normal cases is an injury resulting from the proper exercise of an electrical franchise, and gives rise to no action unless wantonly done or unless done by placing wires in undue proximity to each other. But if the company injured could protect itself by the use of proper modern devices, it has no standing to require its antagonist to bring its own plant up to a higher degree of efficiency than it is willing to provide for itself.

\section{Summary of principles.}

We are now in a position to summarize the authorities thus far discussed.

The street railway is a dominant franchise in city streets. It is a burden upon country highways.

The construction and operation of the street railway cannot, in normal cases be enjoined by any other franchise holder, merely because the exercise of the franchise is harmful to it.

Telephone and telegraph companies may procure a certain degree of immunity from disturbance through induction by using the McCluer device or the complete metallic circuit. Such a company therefore can obtain no relief from the courts unless it can show that it is maintaining its plant at a state of efficiency consistent with modern development in electrical apparatus. The Canadian cases suggest a test in this connection that seems final. A company not making use of such appliances is 
certain to be disturbed sooner or later by some electrical franchise, street railway, electric light or electric power. It cannot hope to exclude forever all other franchises from its territory merely because it fears disturbance when it has voluntarily kept its own apparatus at a low state of efficiency.

All direct trespasses may be restrained. All wanton trespasses may be restrained. It is probable that the direct injury of apparatus or property by escaping currents of electricity is actionable both in England and the United States.

The location of wires and other apparatus will almost invariably be controlled in such a manner as to harmonize the operation of both franchises.

It is evident, however, that the courts have carried to its extreme limit the doctrine that the railway company, as holding a franchise in furtherance of public travel, cannot be held liable for injuries produced by induction. The effect of giving the railway company, and the railway company alone, immunity from responsibility for damage caused by escaping electricity is to give to it a monopoly in the use of the earth as a return circuit. The true rule would seem to be that the railway company should itself adopt a complete metallic circuit in some way, efficient to prevent the escape of electricity from the rails. This would produce comparative equality in the relations of the parties. Interference by means of induction could then be eliminated by having poles and wires located a suitable distance from each other.

The means to be adopted by a railway company or other company to eliminate interference is a matter not for the courts, but for the legislature. 



\section{PART II.}

\section{THE LAW RELATING TO ELECTROLYSIS}

CHAPTER IX.

ELECTROLYSIS.

56. Electrolysis-The problem. Definitions. The Peoria Case.

57. Statement of facts.

58. Determination of existence of electrolysis. Tracing the cause.

59. Notice to defendants.

60. Rapidity of electrolytic action.

61. Elimination of possible explanations.

62. Differences in potential.

63. Suggested remedies.

64. Railways negative return system.

65. Summary of facts.

66. ' Conclusions of law.

67. Electrolysis a permanent and continuing injury.

68. License to operate a railway does not justify injury to others.

69. The injury results from defendant's acts.

70. The injury is actionable.

71. The remedy.

72. Investigation of possible remedies.

73. Metal consumed by electrolysis.

74. Bonding as a remedy.

75. Difference of potential necessary to produce electrolysis

76. Definition of electrical terms.

77. Electrolysis defined.

78. Court eannot specify kind of remedy.

79. Injunction to restrain injury by electrolysis.

80. Principles of general application.

81. Eleetricity a dangerous agent. 
82. English cases of electrolysis.

83. Public and private duties of public service corporations.

84. Municipality may restrain electrolysis.

85. Faulty construction must be remedied.

86. Principles established.

87. Summary of the law relating to electrolysis.

56. Electrolysis-The problem. Definitions. The Peoria Case.

The legal remedy for injuries due to electrolysis is one of the most recent developments of the law of electricity, or more broadly, of the law of torts. The number of cases is very limited and the subject has had extended discussion in but one case. It is certain that this branch of the law is in its infancy, but the cases to be discussed disclose an unusual uniformity of principle. The injury is usually the basis of an action whether done to a private individual or to the holder of another franchise. It is difficult, however, to conceive of a problem in which the facts could by any possibility be more complicated.

The word electrolysis has been given a judicial definition. In the case of Peoria Water Works Company v. The Peoria Railway Company, ${ }^{11}$ electrolysis is defined thus: "Electrolysis is the decomposition of a metal solution in water, liquid ammonia, etc., accompanied by decomposition of the water in the oxygen and hydrogen or of a mass of molten metal, by having an electric current pass through it." The solution or metal mass is known as the electrolyte.

In that case a bill was filed by the water company for an injunction against the injury of the water mains by electrolysis. The plaintiff was granted authority by the city of Peoria to operate the water works of the city, to enlarge and improve the system and to supply water to

(11) Peoria Water Works Company v. The Peoria Railway Company, 181 Fed. Rep. 990, 1910. 
the city of Peoria for a term of thirty years. The city also agreed to adopt ordinances to protect the water company in the safe and unmolested exercise of the franchise, and the license thereby granted. To make the matter clear, we may summarize the position thus: The water company had an absolute franchise from the city to operate its water works, and to lay and maintain its pipes in the city streets. And it was guaranteed by the city the safe and unmolested exercise of its franchise.

\section{Statement of facts.}

The defendant was a street railway company, incorporated by the State of Illinois, and it operated all the street railway lines in the city of Peoria. All of its cars were operated by electricity, and it too had a franchise from the municipality of Peoria giving it the right to occupy the streets of the city and to propel its cars by electricity. So far as priority of right appears in the case, the plaintiff water company had its mains in the streets of Peoria before the defendant railway company, or in fact any railway company had occupied the city streets.

The defendants operate their railway lines by the overhead single trolley system. Electricity generated in the power station of the railway company and used to operate the motors under the cars, is conveyed to them by an overhead wire and a single arm or pole attached to the car and carrying a contact wheel which runs along and underneath the overhead wire. The current passes from this wire down through the wheel and arm to and through the motors, thence to the wheels of the cars and from them to the car tracks or rails. The current then finds its way back to the generator in the power station, and in accordance with an established law of electricity, in so doing follow's the path of least resistance. 
The railway tracks of the defendant's railway, are necessarily uninsulated from, and in electric contact with, the earth, although in the business portion of the city of Peoria, the streets upon which such tracks are laid are for the most part, paved with a brick pavement laid upon a concrete foundation. A part of the return electric current, after going through the car motors, to the tracks, finds its way from the rails through the ground to the water pipes of the complainant, and makes use of them as a part of its circuit back to the generator in the power station. This current (in compliance with the law above referred to) escapes from these pipes into the moist earth which sets up the electrical action which causes the decomposition of the metal pipes, which is similar to the action which takes place in an electroplating bath.

58. Determination of existence of electrolysis. Tracing the cause.

The soil in and around Peoria in which the water pipes and mains of the water company's system are laid, is of a moist, sandy character, and often furnishes a path of comparatively low resistance to the electric current.

Samples of soil which were taken from the immediate vicinity of water company's service pipes, showed traces of lead, which had been deposited there by the action of the electric current. And the metal from these water pipes is frequently found deposited in the form of some of its compounds along the path of the current from the pipe to the rails of the railway companies.

Samples were analyzed from pits in complainant's water pipes and from the soil in the vicinity of such pipes. The materials which came from the pits in the cast iron water pipes were found to be the products of decomposition of the metal in the pipes, resulting from the defendant's cur- 
rent passing through the salts in the surrounding soil. This electrolytic action destroyed many lead service pipes of the complainant. It had resulted at the time the action was brought in pitting and weakening many of the pipes and mains of its water distributing system.

In the months of May and June, I894, an extended examination of the water piping system of the complainant was made by electrical experts and more than $\mathrm{I}, 000$ electrical measurements taken, which showed that at that time there was in every instance a difference of potential, indicating flow of electric current between rails and pipes. This difference of potential or electrical pressure was found to vary in different cases from a fraction of a volt up to 45 volts. The measurements showed that in some places the flow of current was from the rails into the pipes, and in others from the pipes into the rails. Actual tests made at that time showed a loss of metal in single service pipes of over a pound of metal per month, the observations indicating that many other pipes were deteriorating at the same rate. Excavations were made in a number of places for the purpose of inspecting the pipes to ascertain their actual condition. Many of these pipes were found to be wasting away, and there was evidence that rapid electrolytic action was taking place.

\section{Notice to defendant.}

On April 6, I894, the receiver of the Peoria Water Company, who was in possession and operating the water works plant, caused notification to be made to the Central Railway Company "that the Peoria Water Company has been for a long time past, and is now, daily suffering and sustaining great injury and damage to its lead and iron pipes and other underground property in the streets and alleys of Peoria; that it is put to great labor, expense, 
and trouble in making and keeping up repairs on its said pipes by reason of the improper and unlawful use by you of the ground as a return conductor for electrical currents, and by the illegal, careless, and improper use of electrical currents generated by you." Similar notice was given to the mayor and common council of the city of Peoria on or about November 24, I893, December 8, I893, December 19, I893, January 2, I894, and on February 7,1898 , which notices called upon the city for protection under the water works ordinance against damages which the notices alleged were then being suffered.

\section{Rapidity of electrolytic action.}

Another examination of the water piping system owned and operated by the complainant, was made in the early part of 1898 by the same experts who made the examination in 1894 . An electrical survey was made with a view to a comparison between the conditions existing in 1894 and 1898 . The experts found and reported that the destruction was taking place more rapidly in 1898 than in I 894 , and that it was being caused by electrical currents generated by the defendants.

\section{Elimination of possible explanations.}

During the progress of the taking of defendants' testimony in this case, it appeared from the evidence that some of complainant's iron gate boxes were located under the rails of defendants' track, and it was contended by defendants' counsel and experts that enough current was diverted by reason of the proximity of these gate boxes to account for all the electrolysis claimed by the complainant. It was contended by complainant and its experts that in no case did any actual contact exist between the gate box and the rail except in instances while a car was pass- 
ing over a box. Nevertheless, 35 of these gate boxes were taken out and replaced by vitrified tile pipe, a nonconductor of electricity. In other cases the gate boxes were entirely removed, and not replaced because not needed. This change left no gate boxes within one foot from the rails. Examination and tests made by both parties after this change in the gate boxes showed large quantities of electric current from defendants' system still traveling upon complainant's pipes.

\section{Differences of potential.}

In June, I899, and after considerable improvement had been made by the railway companies in the way of heavier rails and better bonding, and an improved return feeder system, another electrical survey was made of the existing conditions between the rails of the railway companies and the water mains of the complainant. This survey showed that a large volume of current was still flowing between the rails of the defendants and the pipes of the complainant, the volt meter showing Io different readings of ro volts and over, the highest found being 35 volts, rails positive to pipes.

A difference in potential of the fraction of a volt will cause electrolysis, and from the conditions hereinabove found and stated the ultimate destruction of complainant's pipes by the currents of electricity allowed to escape from defendants' system is a question only of time and pressure.

The evidence discloses no known method by which the complainant by its own action can protect its water distributing system of pipes and mains from the electric currents of the defendants' single trolley railways.

The evidence discloses no complete remedy for the injury to these water pipes except the entire removal of 
electric currents from the water mains. Such removal is impossible so long as the return currents of the electric railways are grounded or in electrical contact with the earth. The other methods which have been suggested by the defendants in this case do not in practice, and cannot prevent the escape of a portion of the currents into the ground and water pipes.

\section{Suggested remedies.}

The defendants can prevent the injury by controlling the current generated, by means of the use of a complete metallic circuit, insulated from the rails and ground, providing a channel for the return of the current to the generator as perfect as the channel that is provided to supply the power along the street for use. In the District of Columbia, outside of the City of Washington, the double trolley has been and is being installed by a number of roads under acts of Congress providing, in substance, that, where the overhead trolley is used, it must be the double trolley, and also that no portion of the electrical circuit shall under any circumstances be allowed to pass through the earth, and that neither pole nor any dynamo furnishing power to the line shall be grounded. This action by Congress was caused by the interference of the electric current of the single trolley railways with underground metallic structures in Washington and the surrounding territory. The overhead double trolley system has been used in Cincinnati, O., for ten years, and has been shown by experience during that time to be practical, economical, and satisfactory, and the evidence shows that by its use in this case the return current might be carried back to the dynamo without coming in contact with the earth at all, and the difficulty from electrolysis thus be completely overcome. The original cost for installation of the 
double trolley system is considerably more than for the single trolley system. While the evidence in the record as to the exact cost of changing the defendants' system from the single to the double trolley is conflicting and unsatisfactory, it is sufficient to determine the fact that such cost would not be so unreasonable and excessive as to make it impossible for the defendants to adopt the double trolley system.

\section{Railways negative return system.}

The defendants' negative return system is as good as or better than the average used by overhead single trolley electric street railways in cities of the size of Peoria, and the defendants have done all that can be done under the present state of the art, so long as the single trolley is used, to care for the safe return of their electric currents. Notwithstanding this, it clearly appears from the evidence that a portion of the returning currents continues to escape to complainant's piping system and necessarily causes injury, and threatens ultimate destruction thereto.

At least 25 miles of complainant's water mains are laid under streets paved with permanent and expensive pavement, and practically no access can be had to these mains except when made necessary by actual breaks in the pipes. The fact of injury to these mains in this territory from the electric current of defendants is capable of demonstration and has been demonstrated in this case, though it is impossible to determine the exact extent of the injury to the whole system at any given time.

\section{Summary of facts.}

The ultimate facts disclosed by the evidence may be briefly summarized as follows: (I) The injury complained of exists. (2) The injury is permanent and con- 
tinuing. (3) The injury has been and is being caused by the defendants. (4) The complainant can do nothing to prevent the injury. (5) The defendants can prevent it by the use of the overhead double trolley system, or by any system which provides a completely insulated metallic circuit for the electric current. (6) The overhead double trolley system, though more expensive to install, has been demonstrated by use and experience to be as safe, economical, and satisfactory in its operation as the single trolley system.

\section{Conclusions of law.}

Upon this state of facts, the court reached the following conclusions of law:

(I) The court has jurisdiction over the subject-matter in this proceeding.

(2) In Illinois there is vested in municipal corporations the power of exclusive control over the streets, and in many cases a fee-simple title to the streets, and, under the power of exclusive control over the streets, it is well settled by the decisions of the state courts that the municipal authorities may do anything with or allow any use of streets, which is not incompatible with the ends for which they are established and that use for the purpose of water pipes is among those for which the use of streets may be granted, and that the laying of water pipes under ground is much less of an obstruction and interference with the ordinary purposes of a strect than the laying and maintaining of a railway track upon its surface.

(3) In view of the law of Illinois relating to the use of streets, which has become a "rule of property," and therefore will be followed by the federal courts, it cannot be held that the use of the streets for water pipes is in any sense subservient to the use for electric street rail- 
way purposes, assuming that both uses have been granted by the municipality in the proper exercise of its authority.

(4) Both parties to this suit acquired their rights in the streets by a grant under statutory authority from the city of Peoria by ordinance passed by common council. Each occupies the streets by legal authority. Each is performing a duty to the public. Each has money and property invested in its system and plant, a considerable portion of which in each case occupies the streets by such legal authority. Both are entitled to the equal protection of the laws against the invasion of their rights and property by others.

\section{Electrolysis a permanent and continuing injury.}

(5) The injury which is being done to complainant's water pipes by the defendants' currents of electricity is not a mere incidental injury or inconvenience, but is a permanent, continuing injury to a legal right, which will, in effect, if the injury is permitted to go on, ultimately result in the absolute destruction of complainant's plant and property. This would amount to nothing less than the taking away from complainant of the use of its property by the defendant street railway companies which, if it be done under their license from the city, authorizing them to propel their cars by electric motive power, would be a taking of private property for public use. The constitution of Illinois provides that "private property shall not be taken or damaged for public use without just compensation."

68. License to operate a railway does not justify injury to others.

(6) The license from the city of Peoria to the defendants, while it grants the right to them to lay their 
tracks and "propel their cars by electric motive power" does not assume to give the "right" to so construct or operate their systems as to damage the property of others who have equal rights to the use and enjoyment of their own property. A fortiori, this is true because of the fact that it is possible for the defendants to so construct and operate their railways by electric motive power as not to interfere with or injure the water pipes of the complainant. But even if such license did not assume to grant the "right" to operate in the manner in which the defendants are operating, regardless of injury to others, the law would not tolerate such use because of the provisions of the Constitution above quoted.

\section{The injury results from defendant's acts.}

(7) The injury complained of in this case is the direct and immediate result of defendants' acts-as much so as if the defendants were to deliberately uncover and destroy by any other means, the water pipes of complainant. The defendants, by taking the necessary, reasonable precautions in operating their railways, would be able to avoid the injury, and, this being true, their failure to take such precautions, must be considered as negligence. It is as much the duty of the defendants, then, to refrain from injuring the property of the complainant by the one method as it is by the other. The complainant is as much entitled to protection against the injury from defendants' electric currents negligently allowed to stray upon its property, as it would be to protection from the wanton destruction of its property by any other direct means which might be employed by the defendants. The maxim, "Sic utere tuo ut alienum non laedas," applies even under the strictest limitations of the rule which have ever been applied by the courts in any case. 
70. The injury is actionable.

(8) Although the defendants are operating their railways under ordinances from the city, granting them a license to propel cars by electric motive power, and in so doing are interfering with the property and water pipes of complainant, such interference and injury is not damnum absque injuria because: (I) It is possible for the defendants to so operate their railways by electric motive power as not to injure the complainant's property. It is impossible by any known method for the complainant to protect its propenty from such injury. (3) Where there are two methods of accomplishing a legal result and one method will work an injury to another and the other method will not, it is the duty of the person doing the thing to use that method which will not result in injury to such other person. (4) The failure on the part of the defendants to observe such duty constitutes negligence, and, when it results in damage to another, such damage is actionable.

(9) The injury found to be going on in this case is the direct consequence of the unnecessary and wrongful acts of the defendants in accomplishing a legal resultthat is, the propulsion of cars-and, unless the defendants are protected by their license from the city, they are liable to the complainant for such injury. These acts, unnecessary and wrongful in themselves, are not rendered lawful by the ordinance granting the use of the streets for the purpose of propelling cars by electric motive power, and, inasmuch as they work "hurt, inconvenience, and damage" to the complainant, they constitute a nuisance which is actionable at the suit of the injured party.

\section{The remedy.}

(Io) The injury complained of being actionable, 
there can be no doubt of the power of the count to grant some remedy. The damage already done is chargeable to the defendants, so far as such damage is capable of being definitely ascertained, the defendants should be held liable in a suit at law. But a suit and recovery at law would not stop the injury which is and must necessarily be continuous under existing conditions. The very life of complainant's plant and franchise is threatened. The only adequate remedy is therefore by injunction as prayed in the petition. The special master's conclusion is that the bill and evidence make a case of equitable jurisdiction, and that an injunction should be issued as prayed, subject to such reasonable conditions as to the court may seem right.

\section{Investigation of possible remedies.}

The special master's conclusions having led to a full realization of the difficulties of adjusting the rights of the parties litigant, the case was again referred to the same master for the purpose of developing further information on certain points which were directed to an ascertainment of the feasibility of remedying the conditions. These points were as follows:

(a) What remedies can be applied to substantially minimize or prevent the injury, if any, to complainant's water distributing mains and system in and near the city of Peoria, Ill., by the return electrical currents employed by the defendant in the operation of its street railway lines in said city?

(b) The relative merits of the single overhead trolley system and insulated circuit systems of operating street railways, with relation to the leakage of electrical current, and the resulting injury to the underground metallic structures of other public service corporations or in any 
other respect material to the issues herein, as shown by the results of experience or otherwise, since the closing of the proofs in this case.

(c) What are the means now employed by the defendant herein to prevent injury to the underground metallic structures in the streets of Peoria by the return electrical current of the defendant, and the results of the means so employed.

(d) To what extent, if any, have the distributing mains of the complainant company located in the public highways in the city of Peoria been injured or destroyed by the return current of the defendant company, so far as shown by examination made, or anything occurring or ascertained since the closing of the proofs in this case before the special master?

(e) What improvements, if any, have been made by the defendant herein in its electrical return system since the close of defendant's evidence, on the former hearing before said special master?

These queries were answered as follows:

First. In March, I908, the defendant was operating about 50 single track miles of railway lines in the city of Peoria and vicinity. The rails in use were largely of the girder type, 7 inches high, 60 feet long, and weighing 80 pounds per lineal yard. On the streets in the business parts of Peoria these rails were laid on hardwood ties, the latter embedded in concrete, and the space between the rails and between the tracks paved with a hard, vitrified brick, set on edge so as to bring the surface of such pavement even with the top of the rails, the portion of the street adjoining said tracks being also paved with like material in a similar manner. Defendant's return system at the same time consisted of its rails, bonded at each 
rail joint with two No.* copper wires, in a manner commonly known as the "channel pin bond." At the time above specified the defendant was engaged in the application to the rail joints of its system of the "brazed bond," and in March, I908, the latter had been applied to the rail joints, but it is no more efficient in that respect than the welded joint, or certain other methods of bonding, which have been in use for a long time. Where special work existed in the track construction, the rails and tracks were cross-bonded. The defendant also had as a part of such return system about six miles of negative overhead return wires running from its power generating station to different parts of the system, these negative returns at the terminals being connected with rail and tracks, and at the power house with the negative bus-bar of the dynamo. A considerable portion of this work had been done since the close of defendant's evidence on the former hearing, and is in the nature of an improvement to the conductivity of the return system in the way of heavier rails, double rail bonds, cross-bonding, additional negative return feeders, and, so far as had been applied, the brazed bond; but during the same period the average load on defendant's system had been largely increased, probably doubled, and, owing to this increase, and the fact that the large interurban cars are being run over some of the tracks in Peoria, it is more difficult to prevent the escape of electric current to the water pipes of complainant. While the principal purpose of such improvement has been to prevent the escape of the current from defendant's system, the evidence shows that notwithstanding the means so employed the current flow upon complainant's system has gradually increased, a portion of the current has continued to escape and work damage and in-

\footnotetext{
- The report gives no number.
} 
jury to the proximate underground metallic structures, especially to the complainant's water pipes.

\section{Metal consumed by electrolysis.}

Second. Since the closing of proofs on former hearing, the complainant's distributing mains in many instances have been injured, and in some rendered useless, by the return current of the defendant company. In these distributing mains since 1893 there have been discovered joint leaks in the 30 -inch mains, I I9; in the 20 -inch mains, 4 ; in the 16-inch mains, 43 ; in other mains, 47 . Two breaks have occurred in the 30-inch mains, and 9 in the 20-inch mains. Electrical surveys made as late as March 25, I908, showed the most current flowing on the pipes in and about the places where the greatest number of joint leaks and breaks occurred. The pittings in the mains caused by flow of current from defendant's system have been constantly increasing in depth. On South Adams street, where the depth of the pitting, according to the evidence under the former reference, was $\mathrm{I}-8$ of an inch, in March, I908, instances were found where the depth of pitting was $55^{-100}$ of an inch in a main, the total thickness of which is $7-8$ of an inch. The evidence appears conclusive that these pittings, leaks, and breaks have been largely caused by the electric current escaping from the defendant's railway system.

Third. No competent, direct evidence was offered by either party on said question.

\section{Bonding as a remedy.}

Fourth. The defendant offered witnesses who testified, in substance that "all danger of injury" to complainant's water mains and system from electrical currents generated by defendant in the operation of its street rail- 
way could be prevented by the use of the brazed bond on all rail joints in addition to the present bonding, together with proper cross-bonding and "jumpers" thoroughly connecting all rails with each other, in all special work, and proper maintenance of overhead negative return wires as prescribed in said testimony. Some of these same witnesses, also, on cross-examination, testified, in effect, that the plan proposed would not, and could not, wholly prevent the escape of electric current from defendant's system to the water system of complainant, but that the portion of the current that would still leave the rails would be so small and so distributed along complainant's system as to do no damage on leaving the pipes. Complainant's witnesses testified in effect that the plan proposed as aforesaid would not prevent the escape of some current and could not prevent the injury, and that any amount of electric current flowing upon and off the water pipes will cause injury where it leaves the pipe through moist soil, and that such injury is directly proportional to the amount of current flowing during any given period, and this proposition is established by a large preponderance of all the evidence.

Fifth. The evidence offered on this re-reference, and herewith reported, as aforesaid, fails to disclose any method which will completely or substantially prevent the injury complained of, and all the evidence fails to disclose the discovery, since the hearing under the previous order of reference of any new principle or fundamental law regarding the nature and effect of electric currents or of any new method of preventing the escape of such current different in principle from those known at the time of the former hearing. In other words, the evidence of this reference, taken as a whole, tends to confirm the findings 
and conclusions stated in this special master's former report, numbered 14,15 , and 16 , which are as follows:

75. Difference of potential necessary to produce electrolysis.

(14) A difference in potentional of the fraction of a volt may cause electrolysis, and from the conditions hereinbefore found and stated the ultimate destruction of complainant's pipes by the currents of electricity allowed to escape from defendant's system is a question only of time and pressure.

(I5) The evidence discloses no known method by which the complainant by its own action can protect its water distributing system of pipes and mains from the electric currents of the defendant's single trolley railways.

(I6) The evidence discloses no complete remedy for the injury to these water pipes, except the entire removal of electric current from the water mains. Such removal is impossible so long as the return rurrents of the electric railway are grounded or in electrical contact with the earth. The other methods which have been suggested by the defendants in this case do not in practice, and cannot, prevent the escape of a portion of the current into the ground and water pipes.

\section{Definition of electrical terms.}

A definition of some of the terms used by the expert witnesses and by the master in his report is necessary to clearness of discussion.

The "C. G. S." system. Units of electrical force and volume have been fixed by law with reference to what is known as the "centimetergram-second system," generally referred to as "C. G. S." This system was adopted with reference to length, expressed by the centimeter of 39-IOO inches, mass, expressed by the gram, weighing about 
I 5 I-2 grains avoirdupois, and time, expressed by the second. These are the fundamental units of scientific work. Thus the unit of force is that which, when acting on a body weighing one gram, will accelerate that body one centimeter in one second. All electrical measurements are based solely on this force unit, and the electrical units of force, resistance, and volume have been defined by Congress with reference to the C. G. S. system. The unit of resistance, called the "ohm," is $1,000,000,000$ units of the C. G. S. system. The unit of volume, called the "ampere," is one-tenth unit of the C. G. S. system. The unit of pressure, called the "volt," is that electrical force which, when steadily applied to a wire or other conductor having a resistance of $\mathrm{I}, 000,000,000$ units of the C. G. S. system, will produce a current of one-tenth of a unit per second of that system. And the unit of power called the "watt," equals $10,000,000$ units of power in the C. G. S. system, or one ampere times one volt.

"Potential, volt." For practical purposes, it may be said that a dynamo generates electricity and sends it out over the lighting wire or trolley wire at a pressure represented by that number of volts indicated by the work done by the lights or street cars, expressed in watts, kilowatts ( 1,000 watts), or watt hours, where the work continues one or more hours. One horse power is 746 watts or $3-4$ kilowatts. Volts multiplied by amperes gives watts. Thus I IO volts on a lighting wire carrying one-half ampere of volume creates a power of 55 watts. The greater pressure which sends the current out on the circuit over the trolley wire and back through the rails, ground, and water pipes to the dynamo is known as "potential," which may be likened to a head of water in a dam. When the current is leaving the rails and moving into the earth and upon the pipes, the rails are said to be positive to earth 
and pipes; and, when the current moves from the pipes to the rails, the former are positive to the latter. All the battery or dynamo does is to create a difference of potential, or difference of electrical pressure, between two points in an electrical circuit. The unit of that pressure is the volt, equal to the number of units mentioned.

\section{Electrolysis defined.}

"Electrolysis" is the decomposition of a metal solution in water, liquid ammonia, etc., accompanied by decomposition of the water into oxygen and hydrogen, or of a mass of molten metal, by having an electric current passed through it. The metals, carbon, and pure substances generally conduct electricity without decomposition whatever, except at elevated temperatures. The solution or melted mass is known as "electrolyte." The current is introduced to and taken from the electrolyte by means of strips or portions of metal or carbon called "electrodes," connected with wires forming part of the electrical circuit; that by which the current enters being known as the "anode," and the other as the "cathode." In the process of electrolysis minute portions of the metal in solution, and sometimes of the metal in the anode, together with the hydrogen, are deposited upon the cathode, as in silver platings. The oxygen goes to the anode, and tends to oxydize it. The anode is sometimes decomposed in the process and sometimes not, depending on its composition and that of the solution. As applied to water pipes, electrolysis is the stripping off of small particles of the iron when a suitable electrolytic solution is present, leaving the carbon of which the pipe is partly composed intact. What the cathode is in this process of decomposition does not clearly appear, but it may be assumed to be the adjoining water pipe, a gas pipe, lead water-service pipe, 
street car rail, or some metallic deposit in the soil; one or more of these being part of the circuit of the current operating on the water main, and flowing toward the negative side of the dynamo in the railway power station. Pure water, being a nonconductor of electricity, cannot be an electrolyte, but readily becomes such when a portion of metal is dissolved in it, as copper sulphate (blue vitriol), zinc sulphate, silver nitrate, iron oxide (rust), etc. The breaking up of the water into hydrogen and oxygen at once introduces a new resistance to the current, tending to put an immediate end to electrolysis. This resistance, known as "polarization," may be overcome in a variety of ways, among others by applying a higher voltage or potential or by an alternating current. The oxygen going to the water pipe from which the current is passing oxidizes or rusts the pipe, and the coating of rust acts as an insulator, tending to prevent further corrosion of the pipe at that point.

\section{Court cannot specify kind of remedy.}

As to the legal decision of a case of this character, it has been settled that no specific system of evading injury on the part of the railway company can be imposed by the court. ${ }^{12}$ The reason for this decision is that prescribing a definite method of conducting a business is a function of the legislature and not of the courts. ${ }^{13}$

A court of chancery is not any more than is a court of law, clothed with legislative power. It may enforce in its own appropriate ways, the specific performance of an

(12) Atchison T. \& S. F. R. Co. v. The Denver \& N. O. R. K., 110 U. S. 667, (1884).

(13) Express Cases, 117 U. S. 1. 
existing legal obligation arising out of contract law or usage, but it cannot create the obligation. ${ }^{14}$

The reasonableness or propriety of the means to be adopted by electric railroads to lesson injury to gas pipes, water pipes, etc., is essentially an administrative inquiry. Legislative in its nature when considered and administered by the legislature, city council or public service commission; administrative when considered and applied by the corporation itself. ${ }^{15}$

It was decided that the whole duty of the defendant is to make the damage as little as possible by using the best means reasonably within its power, the selection of such means to be left to its discretion, and at its peril to exercise such discretion in a fair, bona fide way. ${ }^{16}$

\section{Injunction to restrain injury by electrolysis.}

The result of this case was that an injunction was granted, enjoining the railroad company from continuing the injury by electrolysis to the complainant's water mains and service pipes, and to be given a reasonable time to take such measures or put in such improvement to its negative return as will substantially prevent injury. This should be upon condition that complainant co-operate with defendant so far as reasonable and proper in aiding it to prevent or lessen the escape of current from its rails or in preventing the escape of current from the water pipes in such a manner as to cause injury thereto. And since everything in the disposition of a case of this nature is of

(14) Atchison, Topeka and Santa Fe. R. Co., v. Denver \& N. O. R. Co., 110 U. S. 667, (1884).

(15) Spring Valley Water Co. v. San Francisco, 165 Fed. Rep. 667-668, (1908).

(16) Peoria Waterworks Company v. Peoria Railway Company, 181 Fed. Rep. 990, at 1004, (1910). 
interest, it is to be noted that the court divided the costs equally between the parties.

\section{Principles of general application.}

While it must be observed that the case just discussed is an action by the gas company against the railway company for injuries to its underground mains, certain principles were established in the course of the discussion that modify to a great extent some of the principles that have hitherto been considered more or less applicable in adjusting such conflicting franchises. First of all, it is to be noted that the court held that underground pipes or conduits of a water company are less of a burden on streets or highways than railway tracks. If this is the case, it applies equally well to the underground conduits, of telephone and telegraph companies. It would seem, therefore, to be established by this decision that a railway company cannot discharge its electricity into the street, and do injury to other franchise holders by consuming their pipes through electrolytic action. To carry the principle one step further, in large centers of population, telephone and telegraph conduits will generally be found under the ground and in those instances it would seem that even in the absence of a statute expressly fixing on the railway company the liability for damage done by electrolysis, the telephone or telegraph companies as well as the water companies may vindicate their rights in either a common law or equitable action. It may be taken also as certain that the court will in no instance define a method by which the railway company or other electric company must remedy the harmful condition. The courts have said that it is entirely within the province of the legislature to say how the railway companies must exercise their franchise, but that this is beyond the province of the courts. The 
most, therefore, that the holders of other franchises can ask from the courts is to enjoin the continuance of a condition which either amounts to a nuisance or causes irreparable injury. The manner in which the defendant will effectuate this will be left to its own discretion.

\section{Electricity a dangerous agent.}

The principle is becoming generally recognized that electricity must take its place with other agents recognized to be dangerous per se. From this results the proposition that the person who employs electricity for his own benefit is almost an insurer that no harm will come to other individuals through its use. The principle which has sometimes been adopted by legislatures is that corporations which are empowered to supply electricity for their own benefit should do so at their own risk and only on the terms that they must bear the loss, if damage is occasioned to an individual, who it must be remembered, may very likely have no interest in the supply of electricity and not be a consumer. ${ }^{17}$ An action was brought against the Corporation of Manchester, which conducts the electric lighting of the city, to recover for damage to property of the plaintiff through an explosion brought about by the operation of the system of electric lighting, maintained by the defendant corporation. The cause of the explosion was a leakage of electricity that had the effect of fusing the bitumen in which an electric main was encased with the result that an inflammable gas was produced which exploded and set fire to premises adjoining those of the plaintiffs. Involved in the decision of the case was the fact that in Clause 70 of the Electric Lighting order of 1890 , which was confirmed by statute, it was

(17) Midwood \& Co., Ltd. v. Manchester Corporation, L. R. (1905) ; 2 K. B. 597, at page 602. 
provided that nothing in this order shall exonerate the undertakers from any indictment, action or other proceeding for nuisance in the event of any nuisance being caused by them. This matter is of interest for the reason that there is a general tendency in various jurisdictions in the United States to couple such a provision with all grants to companies using electricity. It is, therefore, a matter for serious consideration on the part of all companies which seek to avoid liability for nuisance on the ground that the statute authorizes them, whether after all, it is a victory for the company to have the courts uphold the contention that the operation of an electric line is a nuisance, authorized by statute. It is to be recalled that in the rapid development of modern commerce, the tendency in the early days of this development was to regard commerce and the encouragement of property interests as more or less of a god, or if not that, something to be cherished and fostered. The result has been an extreme line of decisions that have tended to exonerate companies using electricity from all the consequences of the natural operation of their plants. This produced, as it was bound to do, a reaction against the companies themselves. For the tendency at present is especially pronounced to specify particularly in all grants of franchises that the holder shall not be exempted from liability if it produces or maintains a condition that amounts to a nuisance. It is, therefore, to the interest of the company becoming aware not merely of defects in its system, but of injuries resulting from its normal use, to remedy such conditions as far as lies in its power, rather than to await the more or less doubtful issue of litigation taken to compel them to perform what really amounts to a duty. The question raised by the case under discussion was whether the defendant could be held liable as for a nuisance, irre- 
spective of negligence. It was decided, first of all, that where the premises of the adjoining owner are blown up by an explosion brought about through the agency of the defendant's system of electric lighting, a nuisance existed. It was further held that there is underlying, a condition imposed for the protection of the public upon an undertaking of such a nature, which is not yet in its final stage of development, and may involve undiscovered dangers, which it would not be fair to throw upon the public. ${ }^{18}$ It will be seen that these cases are driving a great breach in the wall of decisions which, like the case of Rhoads v. Dunbar, in Pennsylvania, throw out the suggestion, that those who live in cities, must abide by the discomforts of city life. They must accept the benefits with the inconveniences. The tendency of the modern cases, however, is to abate nuisances of this character wherever there is any possible legal remedy. The case of Shelfer v. City of London Electric Lighting Company, ${ }^{19}$ is an instance. In the case of Lake Shore and M. S. Railroad Company v. Chicago, L. S. and S. S. Railway Company, ${ }^{20}$ the proposition was laid down that the business of operating an interurban electric railroad as authorized by Burns Awn. St., 1908, section 5675, is not a nuisance per se, but the fact that the business is a lawful one is not necessarily a defense against a charge of nuisance, for a lawful business may be so conducted from its nature or by reason of the surroundings or circumstances as to become a nuisance. In that case, however, an injunction was denied under the following circumstances:

(18) Midwood \& Co., Ltd. v. Manchester Corporation, L. R. (1905) 2 K. B. 597, at page 602.

(19) Shelfer v. City of London Electric Lighting Company, 1895 I Ch. 287.

(20) Lake Shore \& M. S. Railroad Co. v. Chicago L. S. \& S. S. Railway Company, 92 Northeastern 989, (1910). 
The railroad company sought to enjoin an electric railway company from operating its electric railway line on its adjacent right-of-way until it should adopt devices preventing the currents of electricity used from interfering with the use of the telegraph and signal system of the railroad. The injunction was denied, although the railroad company was the first in the field. It was held that the electric company not being guilty of unskillfulness or malice in the construction and operating of its line and the character of the appliance to prevent interference not being disclosed, and it not appearing that the railroad company might not by some inexpensive method prevent the annoyance complained of, an injunction could not be granted. The doctrine of Rylands v. Fletcher, was considered, the plaintiff insisting on the proposition that electricity was a dangerous agent which had been discharged upon its premises, for which the electric railway company was liable. The distinction pointed out by the court was that the use of electricity in the case under discussion was common to both parties and both are acting under legislative grants. The court held, citing National Telephone Company v. Baker, ${ }^{21}$ and other cases of the same nature, that it seems to be the consensus of opinion both in England and in this country that where one is acting under legislative authority and within the right thus given, and reasonably within the exercise thereof, using care and caution regarding the rights of his neighbor, any inconvenience or incidental damage which may arise in the absence of any negligence from the reasonable use of his own property will be regarded as within the rule dammum absque injuria. The statement made in the case of National Telephone Company v. Baker, to the effect

(21) National Telephone Company v. Baker, 1893, L. R. 2 Ch. 186. 
that "the defendants are expressly authorized to use electric power and the legislature must be taken to have contemplated and to have condoned by anticipation, any mischief arising from a reasonable use of such power," has been widely quoted and followed in the United States. Something may be said in this case for the proposition that the plaintiff made no suggestion of any expedient by which the electric railway company could prevent the escape of the electricity, or did not offer any evidence of the expense involved in making changes to protect its own line. Hence, the court further decided, following Eastern and South African Telegraph Company v. Cape Town Tramway Company, ${ }^{22}$ that if the plaintiff were using apparatus so delicate that it could be affected by the ordinary and lawful use of electricity it was bound at its own expense to protect it.

\section{English cases of electrolysis.}

Even in the English cases, however, the electric railway company or electric lighting company is not held to be exempt from liability where electricity escapes from the line of the company and injures water pipes, or other property by electrolysis. In the case of Chepstow Electric Light and Power Company v. Chepstow Gas and Coke Consumers Company, penalties were imposed upon the electric light company for laying their electric line too close to the gas company's mains. The prosecution was brought under section I 8 of the English Electric Lighting act of I899. That act requires electric light companies to give notice before constructing new lines near the mains of gas companies. The case does not state in what way the damage to the gas pipes might arise, but it is to be

(22) Eastern \& South African Telegraph Company v. Cape Town Tramway Company, L. R. 1902, 381. 
assumed that electrolysis was the danger against which the gas company sought protection. ${ }^{23}$

\section{Public and private duties of public service corporations.}

In fixing the liability of companies using electricity for damage due to electrolysis, the courts have made a distinction between the public and the private duties of a public service corporation. In the case of Townsend $v$. Norfolk Railway Light Company, ${ }^{24}$ the court said: "An electric street railway company, is, under the terms of the Constitution of this State, a public service corporation. As such it has duties both of a public and of a private nature. In the operation of its cars in the transportation of freight and passengers it exercises a public duty, and if an injury is inflicted on another in doing what by law it may be required to do, and doing it without negligence, it is damnum absque injuria; and while an electric railway cannot be operated without a power house, still the selection of a site for the power house and the generation of power to propel its cars is the mere private business of the company with which the public has no concern. Such location is a matter of indifference to the public, and, in making it, the company stands on the footing of an individual, and is not entitled to any superior immunities. The grant of legislative and municipal authority to construct and operate its road in a city, does not confer authority to locate a power house where it would be a nuisance, nor authorize the company to molest or to injure the property of others by the operation of a

(23) Chepstow Electric Iight \& Power Company v. Chepstow Gas \& Coke Consumers Company, L. R. (1905) 1 K. B. 198, 1904.

(24) Townsend v. Norfolk Railway Light Company, 105 Va. 22 ; 4 L. R. A. (N. S.) 87, 1906. 
power house, although operated without negligence. If injury to others is inflicted by the operation of such power house the company is liable." Among the damages for which the plaintiff sought to recover in that case, it was alleged that the defendant railway company by allowing the electric current from the wires and conductors or on return circuit to escape from its wires or returning by ground circuit to run over and though the pipes of metal placed . . . to carry water and gas to the houses of plaintiffs, and the plaintiffs' metal pipes thus acting as conductors of electricity caused the pipes to be eaten up and destroyed. It was held that this declaration set forth a nuisance, for which a recovery should be had.

\section{Municipality may restrain electrolysis.}

It would seem that where a city was operating for the benefit of its citizens such an enterprise as the furnishing of gas and water to its people, that it could not be met with the defense by the railway company that it had authorized the injury and could not restrain it. This, however, was partly the conclusion reached in the case of Dayton against the railway company. ${ }^{25}$ In that case, the City of Dayton had authorized the railroad company to propel cars by electricity in the city streets. The city operated its own water supply. An action was brought by the city against the railway corporation to restrain injuries caused by electrolysis. There were certain specific allegations against the manner in which the railway company exercised its franchise. They were:

I. That the railway company has not furnished a metallic circuit, for the return, to the power house of the electricity having been used to propel its cars, and hence the circuit is thus left to return as best it can. It escapes

(25) Dayton v. Railway Company, 26 Ohio, C. C. R. 736. 
from the rails to the earth, and a division of the current takes place, the water pipes of the city receiving a part.

2. That the railway company so imperfectly and inefficiently connected the rails of its tracks, that the return circuit, in a number of places, leaves the rails, escapes into the earth and to the water pipes of the city, and thence back to the earth or rails. That at the points where the return current quits the water pipes returning to the earth or to the rails, the pipes are decomposed, the metal of the pipe removed, and there is left simply the soft material of the chemical compound constituting the pipes. By this action the pipes in some instances have been perforated with holes, at other points split, and in some instances wholly ruined, and in every case weakened.

3. That the city has already been compelled to dig up and replace by new pipe, at a number of places, where the pipes have been so destroyed or so weakened by the action of the return current as described, as to render them unsafe and inefficient to carry the water, and especially under the pressure necessary in case of conflagration. That the injury is still being done and will continue unless the railway company is required to adopt some method to prevent it, and hence is a constant menace to its own property and the lives and property of its citizens.

4. That points where this damage is being done and the extent of it are not accurately known to the city, and cannot be known without digging up all of its pipes; hitherto notice of the injury being done has been brought to the city by leaks from the breaks, and hence not until the damage in such instances was completed. That the injury, if continued, will still be greater, and that it is within the power of the railway company to adopt methods for the return of the electric current after use that 
will wholly prevent its continuance. That the city advised the railway company of the injuries done and of their continuance, and of the city's inability to do anything to prevent them, and demanded of the railway company that it adopt methods known to it to prevent them. But the railway company has taken no steps and still neglects, to adopt some method to prevent the injury being done; that the city is without an adequate remedy at law and therefore prays that a mandatory injunction may issue commanding the railroad company to adopt such methods as will wholly prevent the injuries to the water pipes of the city set forth in its petition.

Its legal obligation to use reasonable care to prevent the electricity escaping from its rails to the water pipes of the city is admitted, but it avers that it has exercised such care and diligence.

It also averred that it proposed a method of protection and to remedy the claimed mischief to the city officials, but this proposition was declined, and none was ever proposed or suggested by the city. That the petition of the city does not inform the defendant what system the court should compel the defendant to adopt.

The defendant admitted the knowledge of the system of double trolley being in use in the cities of Cincinnati and New York, and the conduit system in the city of Washington, District of Columbia, but claims that the adoption of either system would not obviate the danger or protect the water pipes of the city, so long as the other street railways in the city mentioned operate with the single trolley. It claims that the conduit system is impracticable and that the double trolley would involve an outlay of a very large sum of money, in the reconstruction of its road, largely increase the danger to its employes, requiring the use of so large a number of addi- 
tional wires as to greatly increase the difficulty of handling fires.

At the time the defendant equipped its road, the single overhead trolley was thought to be, and so pronounced, by persons experienced in the use of electricity as a motive power for the operation of street railways, as compared at least with the double trolley, the more simple, less liable to disarrangement, much cheaper, less liable to accident in blockading cars and less dangerous to its employes, and the most approved. There was but one road in the United States operated by the double trolley. It was contemplated by the parties at the time that, in the application of the current as a motive power, poles and wires were to be used, as the grant specifies the kind of poles, the distance the same were to be set apart and that the location of the same was to be decided by the city's engineer.

It was also provided how high above the surface of the streets the wires used to convey the current to the cars should be suspended. Therefore, it was contemplated that the equipment was to be a trolley system. Part of the process of equipment was to be under the supervision of the city's engineer. The work proceeded and was of a character that necessarily required personal observation of the authorized officials of the city during its progress. The streets were torn up and their use by travelers necessarily at times interfered with, and the material necessary to the equipment by a single trolley placed upon the streets in plain view, and at the time, and since the equipment of the defendant's road, several street railways within the city, under special grants of the city, have been equipped with, and are now operated by the same system. The White Line began operating with the same system in I888, and in I893 injury by electrolysis to lead service 
pipes was discovered. The testimony does not show that this injury was due to the system; in fact, it does not seem to have attracted much attention.

It was said that under the grant to the defendant by the city to equip with the single trolley, in the use of that system the defendant would be liable only for actual negligence. In granting such right the city must be taken to have contemplated, and condoned by anticipation, any mischief arising from the reasonable use of such system. ${ }^{26}$

When a corporation is exercising delegated authority for the public benefit by the use of due care, no action will lie against the corporation resulting from the proper exercise of the authority. ${ }^{27}$

\section{Faulty construction must be remedied.}

The court held:

I. The law authorizes the action of the city.

2. The case presented does not authorize the court to require the defendant to change to another system.

3. The faulty construction of the defendant's road and negligent operation of the same result in a continual damage to the water pipes of the city for which it has no adequate remedy at law.

4. The fact that other electric railways operated in the city by the same system are in part responsible for the injury to the city's water pipes constitutes no defense for the defendant.

5. The defendant will be enjoined from operating its road in the condition shown by the evidence, and from negligently operating the same.

Jurisdiction of the case will be retained, to give the de-

(26) Telegraph Co. v. Baker, 2 Ch. Div. L. R. 1893, 186.

(27) Hudson River Tel. Co. v. Railway, 135 N. Y. 393; 32 N. E. $148 ; 17$ L. R. A. $674,1892$. 
fendant an opportunity to show what, if any, improvement it has made since the cause was submitted to the court, in the way of bringing up the construction of its road and operating the same.

\section{Principles established.}

The following principles were established in this case:

A street railway company which is operating with a single trolley system, under a franchise granted by the municipality, is only liable for damages resulting from its actual negligence in the use of such system. The municipality will be held, in granting such franchise, to have contemplated and condoned by anticipation any mischief arising from the reasonable use of such system.

Where there is a sharp conflict in the evidence, including the testimony of expert witnesses, as to whether or not the present system under which an electric street railway company is operating is a proper system, a case is not presented which will authorize a court of equity in requiring the company to change to another system.

The fact that other electric street railway companies operating within a muncipality by the same system are partly responsible for injury resulting to the city's water pipes from electrolysis, constitutes no defense to the company against whom the action is brought.

Injunction will lie, at the suit of a municipality, to restrain an electric street railway company from operating its system in such manner as to allow its electricity to escape into the ground and come in contact with and injure the water pipes of the municipality.

\section{Summary of the law relating to electrolysis.}

These cases represent practically the entire field of the law, in so far as it relates to direct trespasses due to the 
use of electricity producing electrolytic phenomena. They indicate clearly, however, the probable trend of authority. For a direct trespass, after all, is a direct trespass, and governed by the same principles whether the harm-producing agent is electricity or gunpowder or water. Professor Francis H. Bohlen, of the University of Pennsylvania, in a thoughtful monograph on the rule in Rylands $v$. Fletcher, ${ }^{28}$ points out that one might regard the distinction drawn between substances whose dangerous qualities give them commercial value and those whose value is not so determined, as being as "unimportant as it is unsound," were it not for the fact that in the case of Marsh v. Lake Shore Electric Railway Company, ${ }^{29}$ one of the Circuit Courts of Ohio held that electricity being, like steam, a substance valuable not because of its danger but because of its usefulness, those using it are not insurers of the safety of others coming into contact with it, but should only be "held to the exercise of care commensurate with its deadly qualities."

It is certain that the case referred to is not in accord with the trend of modern authority. Without discussing matters foreign to the author's purpose it is sufficient to say that electricity has come to be regarded as an agent so manifestly capable of producing harm that the user is held to a degree of care commensurate not with its commercial value, but with its dcadly qualities or possibilities; in other words, the commercial value of a harm-producing agent has no logical place, either in defeating a recovery or in mitigation of damages.

It is manifest that if the courts once establish elec-

(28) Rylands v. Fletcher, 59 University of Pennsylvania Law Review and American Law Register, at p. 439.

(29) Marsh v. Lake Shore Electric Railway Company, 5 Alio C. C. R. (N. S.) 405, 1905. 
trolysis as a permissive harm, necessarily incident to the exercise of an electrical franchise, that not only water pipes, but steel buildings and all other metallic structures may be destroyed with impunity. The court has refused to take this step. It has defined electrolysis as an actionable wrong. As to the remedy, the continuing injury has been restrained in equity, and damages for the injury done have been awarded in an action as upon a nuisance.

It should be observed in conclusion that it seems immaterial whether the person asserting injury to himself is a private owner or the holder of another franchise. Redress has been given in both instances.

In conclusion, the author submits his own view, that the tendency of the law should be to restrict the field of permissive injuries even though authorized by law. It is proper to require one franchise-holder seeking redress to have his plant near the maximum efficiency dictated by modern scientific knowledge, but it is unfair to permit an invader to make the choice of the more convenient and less costly of two methods of operation, and answer the complainant by setting up a statutory authority to maintain a nuisance. The true rule is beyond doubt that established in the case of the Peoria Water Works v. Peoria Railway Company, supra; that the railway company must exercise its franchise so as not to produce harm. To do less than this would be to grant to one holder of an electric franchise what the courts have always refused; a monopoly in the use of the earth as a return circuit. 


\section{INDEX.}

ABUTTING OWNERS,

PAGE ehange from horse power to electric power cannot be enjoined by, 53 damages for injuries due to erection of poles, $\quad 69$ elevated railroads may not deprive of light and access, 17 injuries by electric railways must be paid for, $\quad 53$

ACTIONS,

kind of relief open to electric companies in case of interference,

BILL IN EQUITY,

Telephone v. Railway,

CANADA, conflicting uses of electricity,

C. G. S. SYSTEM, definition of,

CITIZENS,

franchise holders distinguished from,

rights inviolable,

CONDUCTION,

telephone company may recover cost of injury by,

CONFLICTING USES OF ELECTRICITY,

contrast of English and American principles,

DAMAGES,

not recoverable for reasonable exercise of franchise rights,

DANGEROUS AGENTS,

electricity as,

application of principle to use of electricity.

DEFINITIONS,

electrical terms,

electrolysis,

highways,

potential,

volt,

110

110

DELICATE TRADE APPARATUS, owner must protect from interference, 
DOMINANT FRANCHISES, electric light company considered as, $\quad 70$

DOMINANT USE OF HIGHWAY, application of principle,

DOUBLE TROLLEY SYSTEM, elimination of interference by, preventive against electrolysis,

street railways not compelled to use, $\quad 53$

ELECTRICITY,

dangerous agent,

proper motive power for railways,

ELECTRIC LIGHT COMPANIES,

approach too close to telephone wires may be restrained, 42

damages for causing explosion, 115

erection of guard wires may be compelled. $\quad 42$

facilitation of travel by, $\quad 70$

public contract as giving superior right, 54

restraining interference with telegraph companies, 39

right to destroy wires of private owners, $\quad 66$

voltage used,

ELECTRIC POWER COMPANY,

the effect of placing high voltages near low voltages, 62

ELECTRIC RAILWAY POLES,

citizens cannot compel removal by mandamus,

ELECTRIC RAILWAYS,

abutting owners cannot enjoin erection of,

city may restrain operation for electrolysis,

license to operate condones harm from operation,

nuisance from operation of power house may be

abated, 120

public and private duties of,

railroad may not enjoin operation for interference of currents,

voltages used,

ELECTROLYSIS,

bonding of rails as remedy for,

court cannot specify kind of remedy,

definition,

determination of existence,

difference of potential necessary to cause,

electric railway may be enjoined from continuing injuries by,

fixing damage due to, 
injunction to restrain injury by,

injury due to electrolysis, accountability for,

113

judicial definition,

103

law relating to,

loss of metal in water pipes by,

metal consumed by,

municipality may restrain,

not a permissible harm,

permanent and continuing injury,

private owner may restrain injury due to,

ELEVATED RAILROADS, burden upon highways, engine house may not be erected if a nuisance,

EMINENT DOMAIN,

telephone companies have not the right of,

ENGINE HOUSE,

injunction against erection if a nuisance,

ENGLAND,

electrolysis-restraint of injury to water pipes, telegraph and telephone cables protected from damage by ships' anchors, EQUITY,

adjustment of conflicting uses of electricity in,

EXCLUSIVE PRIVILEGES,

franchises do not confer,

grant will not prevent later companies from entering field, when priority of franchise confers,

EXCLUSIVE RIGHTS,

holders of electric franchises do not have,

FRANCHISES,

rights based on contract or license,

accommodation of conflicts,

conflicts in the exercise of,

courts may not restrict use of,

courts may not specify manner of using, 
first holder not to be disturbed,

injury due to lawful operation distinet from aggression,

invasion by second company forbidden,

later occupant must give way to former if interference is unavoidable,

nature of,

persons harmed have no remedy if lawfully exercised,

priority in given territory gives vested rights,

relative values of,

telephone subordinate to railway,

work to be executed in authorized manner, at authorized place,

GUARD WIRES,

jury to determine if failure to erect is negligence, ordinances requiring,

HIGH VOLTAGES, effect of placing lines near low voltages,

HIGHW AYS,

see Dominant use of highway.

definition of,

dominant use of,

electric light poles as burden on,

public property,

street railways a burden in the country,

telegraphs burden,

telephones burden,

use for travel superior to all others,

HORSE RAILWAY, new method of using street,

INDUCTION,

distinction between injuries by induction and conduction,

first electric company in the field may restrain interference by,

telephone company's duty to protect itself against,

INJUNCTIONS,

abuse of franchise ground for,

abutting owners canmot enjoin erection of electric railways,

electrolysis may be restrained by, 
invasion of franchise may be restrained by,

private wires may be enjoined from interfering with electric light wires,

railroad cannot enjoin interference with telegraphs and signals,

telephone eompany cannot enjoin street railway operation in England,

telephone wires may be erected near electric light wires,

\section{INTERFERENCE OF CURRENTS,}

compensation to telephone company for remedying, $\quad 77$

double trolley system may prevent,

first licensee may restrain,

metallic circuit may prevent,

restraint by injunction,

storage battery may prevent,

LAND OWNERS,

franchise holder is to a certain extent,

MANDAMUS,

citizens cannot compel removal of electric railway poles by,

erection of guard wires may be enforced by,

MCCLUER DEVICE,

properly equipped telephone apparatus,

telephone companies to protect themselves by means of

METALLIC CIRCUIT, elimination of interference of currents by, necessary part of properly equipped telephone apparatus, properly equipped telephone apparatus,

telephone companies to protect themselves by means of 26

telephone company may recover cost of installing,

MONOPOLY, electric companies first in the field not entitled to,

MOTIVE POWER, railways may adopt better, railways not bound by choice of,

\section{MUNICIPALITIES,}

injury to water pipes by electrolysis may be restrained

by, 
NAVIGATION.

telephone and telegraph cables not to interfere with, 8

vessels have paramount right to,

NEGATIVE RETURN SYSTEM, street railway eliminating electrolysis by adopting,

NEGLIGENCE,

placing wires of high voltage near telephone wires no evidence of,

NUISANCE,

discharge of electricity into the earth as a,

engine house of elevated railroad not to be erected if a nuisance,

facility of travel no compensation for,

railway operation may be enjoined if a nuisance,

restraint of uses of electricity constituting,

things authorized by competent authority not considered as,

work authorized by law cannot be,

DINANCES,

enforcing guard wire ordinance by mandamus,

POTENTIAL,

definition,

PRIORITY,

monopoly not given by,

railways or telephone companies not helped by,

rights in conflict of railway and telephone, not determined by,

PRIVATE PROPERTY,

franchise holders not to take,

PRIVATE USES, public use superior to,

PROPERTY RIGHT,

franchise holder to be protected,

electric company to be protected from invasion of,

PUBLIC CONTRACTS,

electric light company given priority by,

PUBLIC NUISANCES, private citizen may not redress,

PUBLIC SERVICE CORPORATIONS, relative importance of franchises,

PUBLIC TRAVEL,

railways not to interfere with, 
telephone company cannot complain of improvements in, 48 telephones and telegraphs not to interfere with,

RAILROAD SIGNALS, interference with signals no ground for enjoining operation of electric railways,

RAILWAY TRACKS, burden highway more than water pipes, $\quad 100$ public has the right to use,

RETURN CIRCUIT, monopoly in use of earth for, forbidden,

RYLANDS v. FLETCHER, application of doctrine of conflicts in the use of electricity,

Francis H. Bohlen, monograph on,

SERVITUDES, electric light poles as burden on highway,

SINGLE TROLLEY SYSTEM, action to enjoin use of,

SPRAGUE SYSTEM, lawful for propulsion of cars,

STATUTORY AUTHORITY, answers claim that franchise is a nuisance,

STATUTORY IMMUNITY, effects of doctrine,

STREET RAILWAY COMPANIES, aggression by other franchise holders forbidden, direct interference with telephones enjoined, extent of right to invade other franchises,

STREET RAILWAYS, abutting owners may not prevent operation of, burden on country highways, change of motive power does not burden highway, courts cannot dictate means of preventing injury, defective construction must be remedied, dominant franchises in streets, 
lines may not be placed too close to telephone lines, 37 negative return system, $\quad 99$ operation in streets a proper use, $\quad 81$ operation may not be enjoined, 21 public travel facilitated by, 5 telephone company cannot enjoin operation in England, 49 STREETS,

dominant use of,

franchise owners have no easement in, $\quad 17$

public may use part occupied by tracks, ${ }^{\circ}$

public property, 5

railways have not exclusive use of, 11

SUBMARINE CABLES,

street railway may not be enjoined from inducing currents on,

street railway may not be enjoined from interfering by induction,

trolley interference with,

TELEGRAMS,

telephone messages are,

TELEGRAPH CABLES, navigation must not be interfered with by, ships' anchors not to interfere in England,

TELEGRAPH COMPANIES, service impossible near high voltages, telephone companies are, voltages used,

\section{1}

5

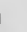

TELEGRAPH POLES, additional burden on the highway, $\quad 10$ not servitude on bighway, $\quad 71$

TELEGRAPHS, interference with railroad telegraph no ground for enjoining electric railway, $\begin{array}{ll}\text { public vehicle of intelligence, } & 7\end{array}$ $\begin{array}{ll}\text { telephone embraced by, } & 7\end{array}$

TELEPHONE CABLES, ships' anchors not to interfere in England,

TELEPHONE COMPANIES,

duty to anticipate improvements in public travel, efficient apparatus to be used,

electric light companies may be compelled to guard wires of,

erection of poles and wires gives vested rights, 
first company in field has superior rights,

franchise subordinate to rights of public travel, paralleling or over building lines forbidden where it interferes,

re-adjustment of methods to prevent interference, recovery of cost of eliminating interference of currents by street railway, relief denied if plant not in high state of efficiency, remedy where wires of high voltages are placed too near, service impossible near high voltages, street railways may not be obstructed by, street railway must pay cost of eliminating interference, telegraph company includes, voltages used,

TELEPHONE MESSAGES, telegrams,

TELEPHONES, public vehicle of intelligence,

THOMPSON-HOUSTON SYSTEM, lawful for propulsion of cars,

TRESPASS,

direct trespass by electrical companies may be restrained,

TROLLEY POLES, abutting owners cannot enjoin erection of,

VOLT, definition,

VOLTAGE, power used by various public service companies,

WATER COMPANIES, injunetion against electrolysis from operation of street railway,

WATER PIPES, amount of metal consumed by electrolysis, less burden in highway than railway tracks, 
loss of metal due to electrolysis, rapidity of electrolytic action in,

WIRES,

erection of telephone wires near electric light wires may be enjoined,

location may be controlled,

regulation of distance between wires of different companies,

regulation of distance to be maintained between high and low voltages, 









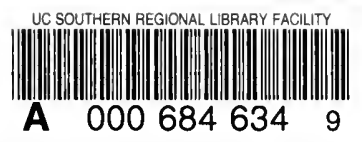


